\title{
القيه الإسلامية وأثرها في الاستقرار الأسري
}

\section{د. فاطمة عبدالرحمن عبدالله}

أستاذ مشارك بجامعة القرآن الكريم والعلوم الإسلامية

مقدمة :

بسم الله والحمد لله و الصدلاة والسـلام على الهبعوث رحمهة للعالهين سيدنا محهد صلى الله عليه وسلم وعلى آله وصحبـه ومـن سـار على هديـ • إلى يوم الدين

فقد أو لت الشريعة الإسلامية التي بُعث بها خاتم النبيين محمدد صلى الله عليه وسلهم للناس كافة أهمية كبيرة •وقد قرر الإسدلام الهبادئ والقو اعد التي تُؤسس عليها الأسرة والتي تكفل لها حياة فاضلة تقوم على معاني المودة

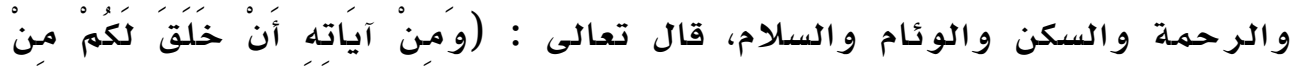

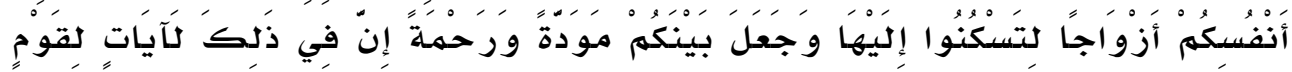

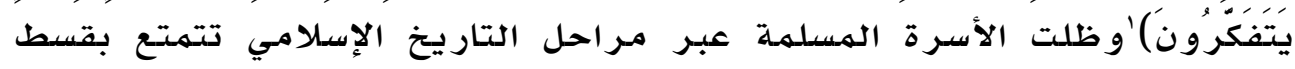
و افر من القيهم الإسـلامية قيهم التراحهم والتعاطف والتآلف والتكافل، وقيهم الإحسـان و التعاون على البر و التقوى، و قيم احتر ام الكبير و العطف على الصغير، و قيهم الإيثار و المحبـة والكلهمة الطيبة ووصلة الرحم، ومن ثهم كان لها دورها

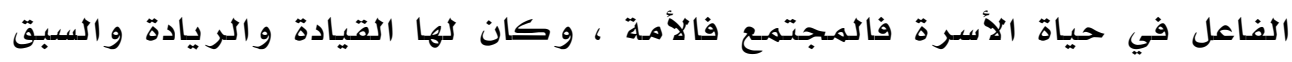
الحضاري الذي أنار للغرب طريق العلدم والتقدم •وفي العصر الحديث هبت على الأسرة رياح التغريب و سـاعد في ذلك تبعيـة العاله الإسدلامي وخضدوعه للاحتلال الغربي، الذي لهم يكن غزواً لكلأرض و انتهاباً للثروة و امتهاناً للكر امهة فحسب، إنهما

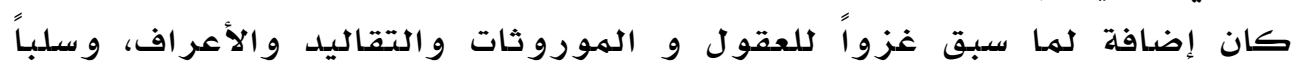
للشخصية المسلمـة، مها زحزح الأسـرة عن خصائصها وقيمها، ففقدت ريادتها

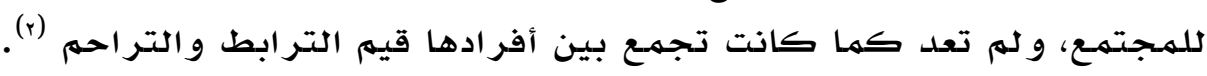

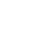


المبحث الأول : مفاهيم ومصطلحات البحث

المطلب الأول : مفهوم القيم والقيم الإسلامية وخصائصها :

المسلك الأول : مفهوم القيم

القيم لغة: القيهمة (ثبات الشيء ودوامه)(r).يقال (فلان ماله قيهمة إذا لهم

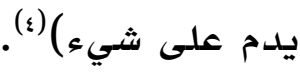

القيمة لدى المختصين في علم النفس والاجتماع:

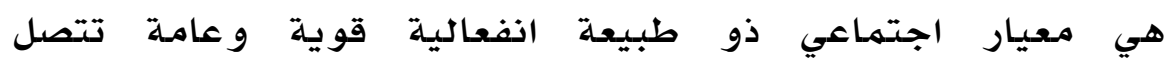

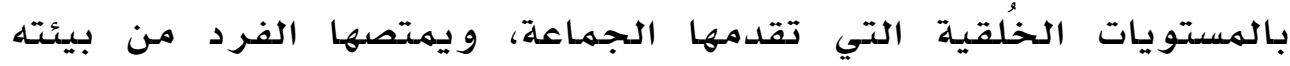

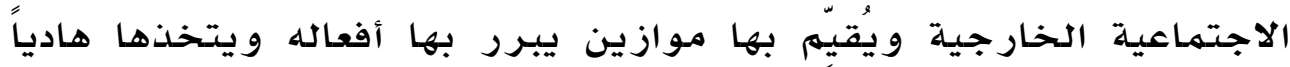

$$
\text { و مـر شداً (ه). }
$$

المسلك الثاني : مفهوم القيم الإسلامية:

هي مجموعة من الأحكام و المعايير النابعة من تصورات أساسية عن الاسل

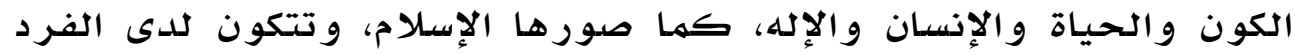

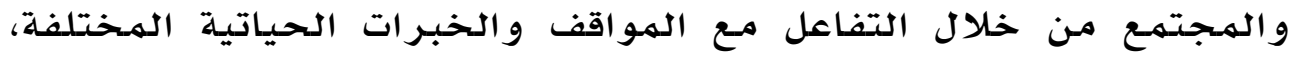

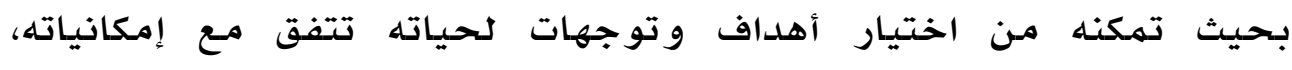

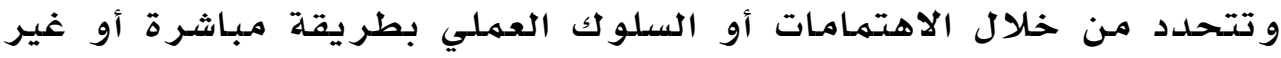

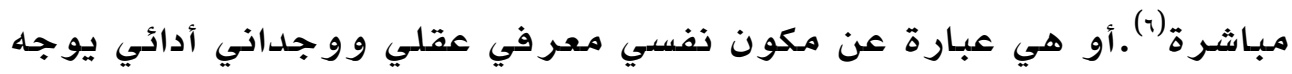

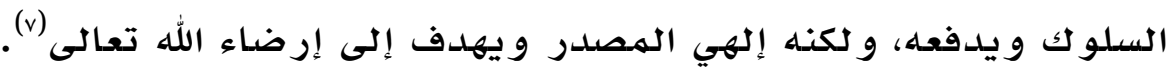
و يمكن أن تعرف بأنها مهجموعة من الهُثل العليا والغايات و المعتقدات

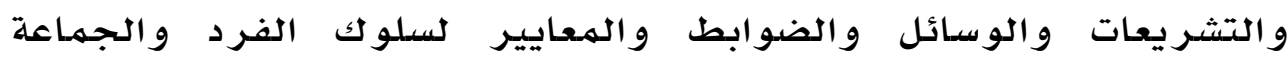

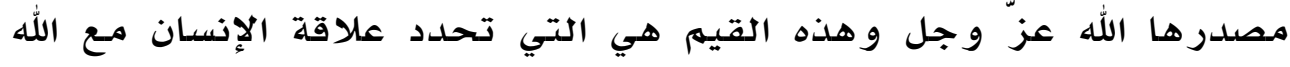
و مـع نفسه ومـع البشر وهـ الله عز الكون (^). 
المسلك الثالث : خصائسص القيم الإسلامية:

\section{تتميز القيم الإسلامية بالخصائص التالية:}

أولاً : أنها تستمد مـن القر آن الكريهم والسنـة النبوية الهطهرة.

ثانياً: أنها تستمدد من الأحكام الشرعية باعتبار أن” الحياة الإسلامية كلها تقوم على هذه الأحكام التي تحدد توجيهات الإنسان في حياته حيال الأشياء

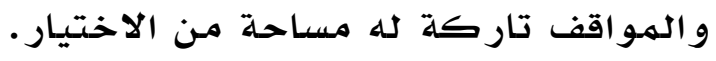

ثالثاً: أنها تقوم على أساس الشمول و التكامل، أي أنها تراعي عالم الإنسان

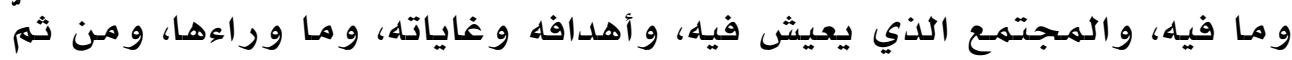

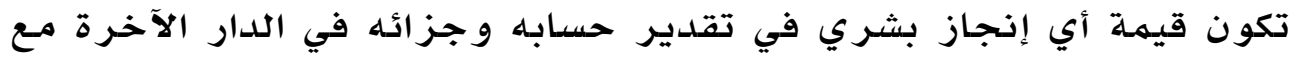
عدم إهمال الدنيا.

رابعاً: أنها تقوم على مبدأ التوحيد باعتباره النواة التي تجتهـع حولها

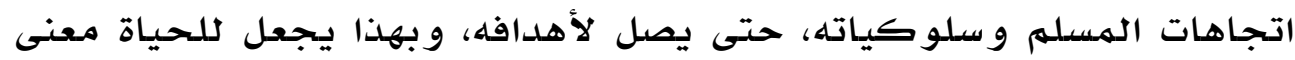
وو ظيفة.

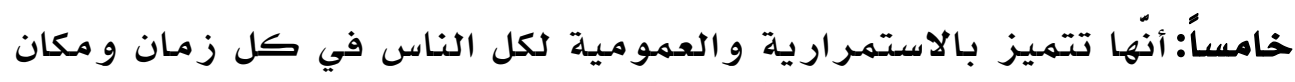

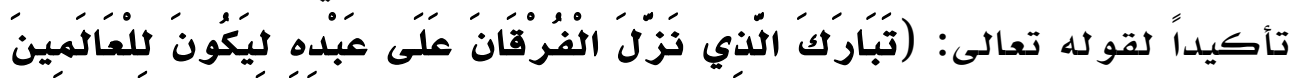

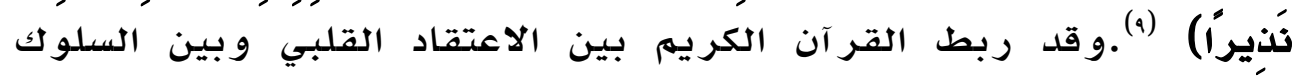

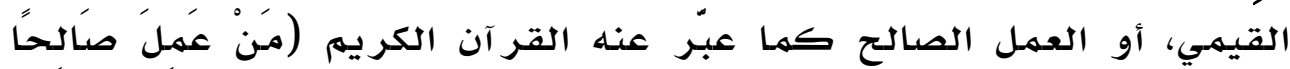

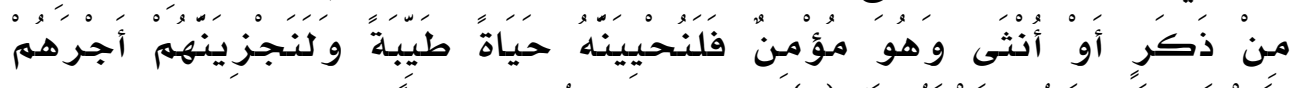

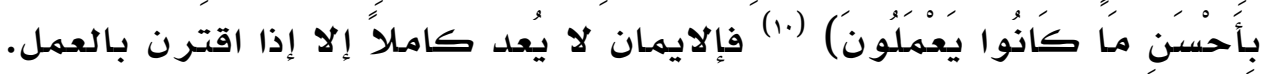
فالسلوك الإنساني القويهم منبعه العقيدة الصحيحة، وأنة العقيدة

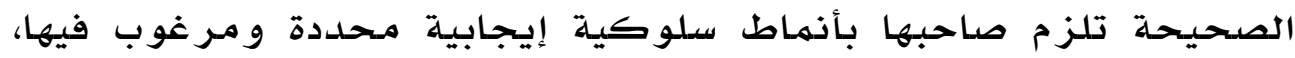
و تبعده عن أنهاط سلوكية سلبيـة غير مر غوب فيها.

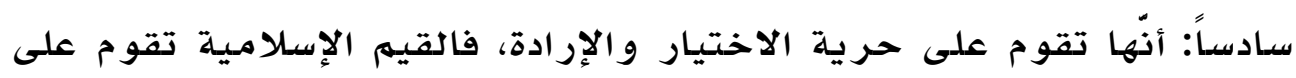

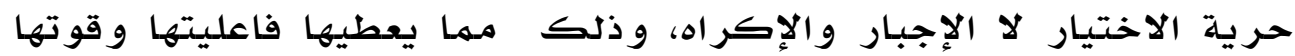


الإلزاميلة و لكنها في الوقت ذاته تربط بين الحرية والإرادة، وبين

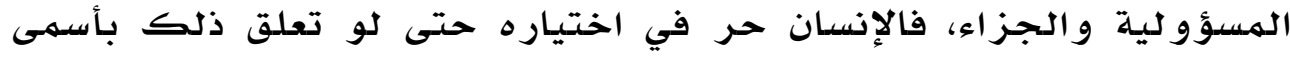

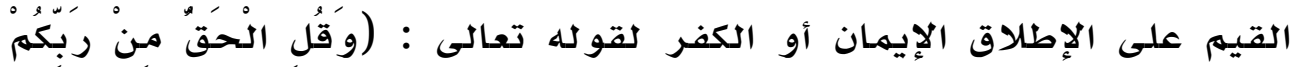

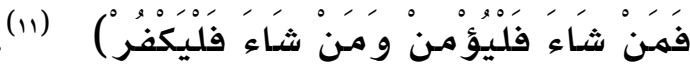
سـابعاً :أنّ تنمية القيه عملية تعاونية و من خصائص القيهم أن تقوم منظو مـة

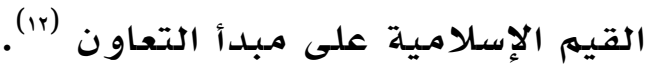
ثامناً :الوسطية: وذلك بأنها لهم تلغ الطبيعة البشرية فهي لا تضاد الفطرة

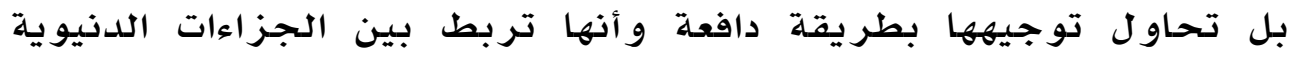

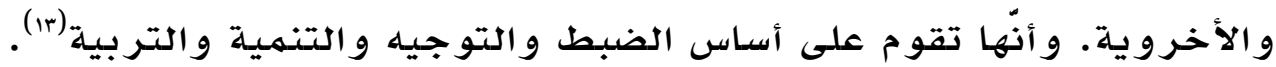
المطلب الثاني : مفهوم الأسرة والاستقرار الأسري : المسلك الأول مفهوم الأسرة ومقاصدها في الشريعة الإسلامية :

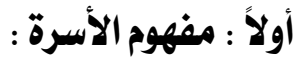

الأسرة لغه : هي الدرع الحهون الحصين، و أهل الرجل و عشيرتة،ويطلق علي

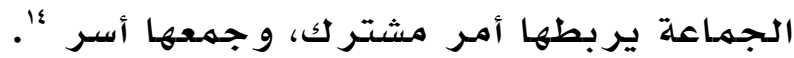

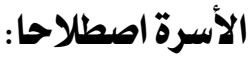

هي الوحده الاجتماعية التي تتكون من رجل و امـر أة بعقد شرعي يسهـح

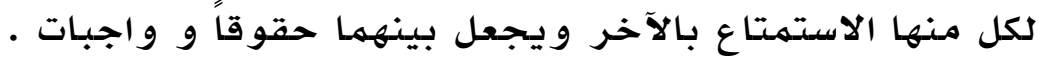
ثانياً : مقاصد تكوين الأسرة:

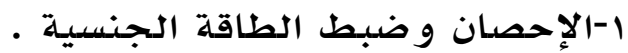
r-الإنجاب و حفظ النوع الإنساني • r-حفظ الأنساب ع- سلامة الهجتمـع من الانحلال الخلقي . 
؟- تربية الأجيال التي تعبد الله وتخشاه و تعمر الأرض

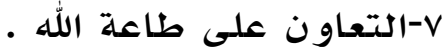

^-حفظ المهتهـع من الأمر اض المنقو لة جنسياً . المسلك الثاني : مفهوم الإستقرار الأسري وأهميته : أولاً : مفهوم الاستقرار الأسري :

أولاً : معنى الاستقرارلغة : استقر ار: مصدر، يقال : عرف الطقس استقر اراً أي

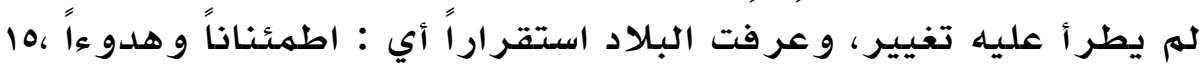
فنجد أن الاستقرار في معاجم اللغة العربية يلدور حول الهدوء والثبات

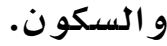

ثانياً : معنى الاستقرار الهأسري : إذا قامت العلاقة بين الزوجين على أساس من السكينة والثبات والتوازن؛

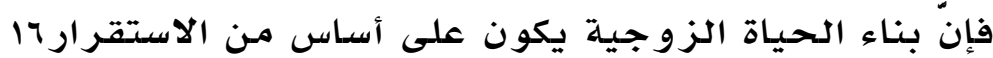
و عليه فيمكن أن يقال أن" الاستقرار الأسري هو : بناء علاقة زوجية تقوم على السكينة و الثبات و الهلدوء و التوازن و التكامل بين الرجل و الهـر أة . ثالثا : أهمية الاستقرار الأسري :

تنبع أهمية الاستقرار الأسري من أنّ الأسرة هي أهمٍ مكون في جسم

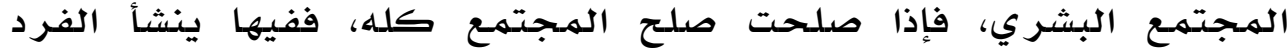

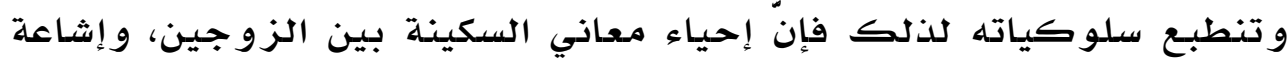
قيهم الهودة والرحمة داخل الأسرة يساعد على أن يكتسب الطفل اتجاهاته،

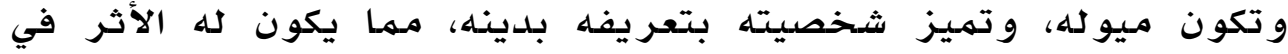
تقويم السلولك و بعث الطمأنينة في نفسه. وهنا تكمن أهميلة و محورية دور 
الأسرة في التربية. فكثير من الهشاكل التي تواجهها أمتنا حاليا منبعها

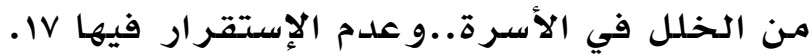

المطلب الثالث : مفهوم السنة النبوية :

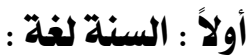

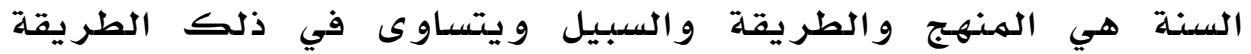

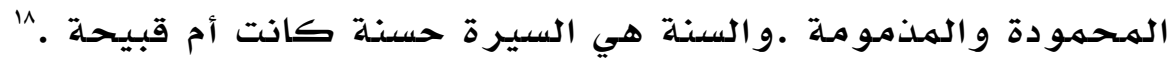

ثانياً : السنة اصطلاحماً :

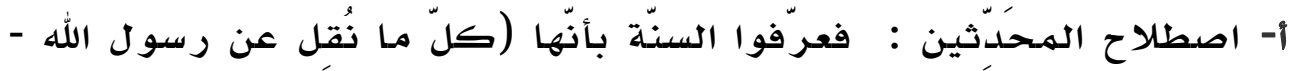

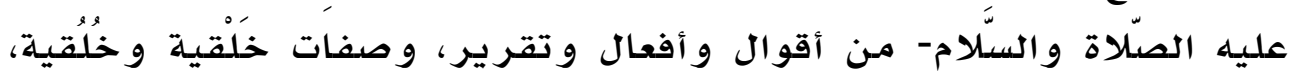

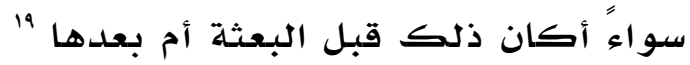

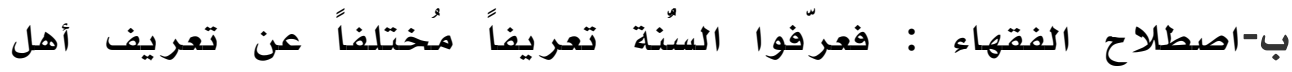

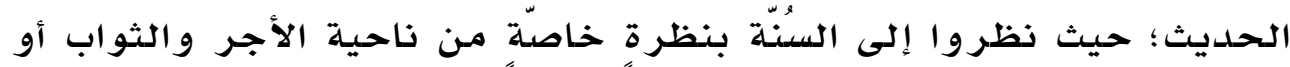

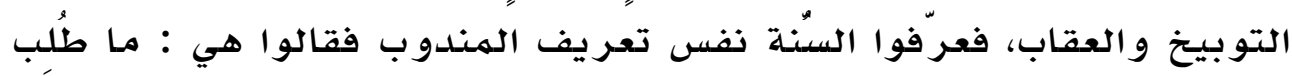

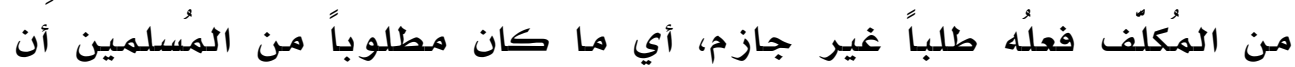

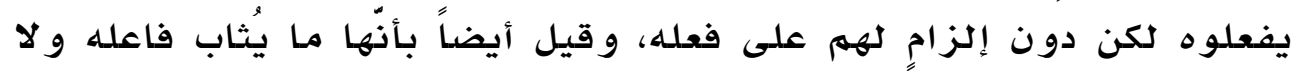

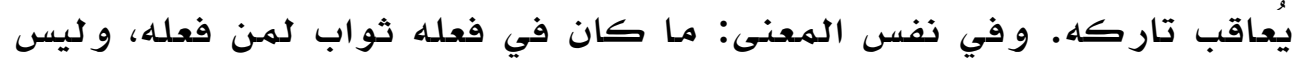

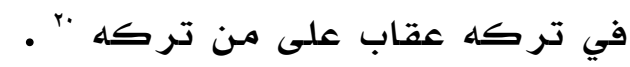

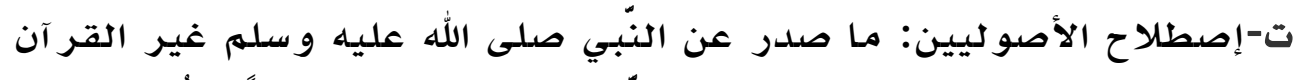

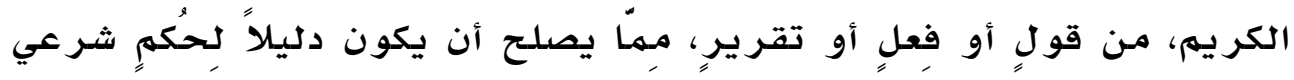

ث-كما عرفت بأنها : طريقة النبي صلى الله عليه وسلهم التي كان

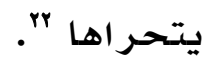
و منهج المحدثين في تناول السنة النبوية ودراستها هو مانريده في هذا

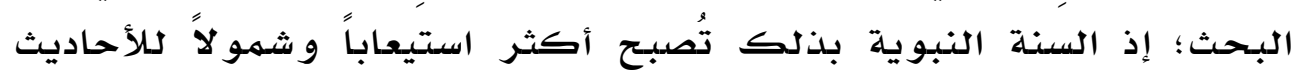
النبو يـة البحة 
المبحث الثاني : القيم الأسرية الواردة في السنة النبوية :

الاطلب الأول : القيم الأسرية التعلقة بالحياة الزوجية الواردة في السنة النبوية :

تتمثل القيهم الأخلاقية كها وردت في السنة النبوية وكها حققها الرسول الكريهم صلى الله عليه وسلم في حياته الزو جيـة في :

1 - حسن الخخلق وحسن المعاملة :

من العوامل المسساعدة على نجاح الحياة الزوجية حسن الخلق

وحسن الهعاملة بين أفراد الأسرة ، وقد حرص الإسلام على تماسك الأسـرة وأوصى بحسن التعامل مـع النسـاء فقال صلى الله عليه وسلهم في

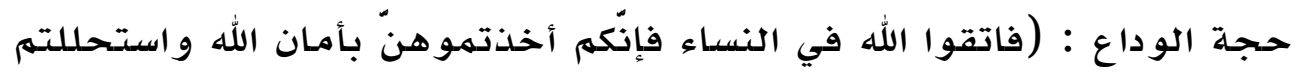
فروجهن" بكلمهة الله و لكم عليهن أن لايوطئن فرشكم أحداً تكرهون) •و تمامـا لهذه الوصيـة فقد جعل الإسـلام مـيزان الخيرية والخلق للرجل هو مقدار حسن العشرة لزوجته وحسن معاملته لها، (عن أبي هريرة- رضي

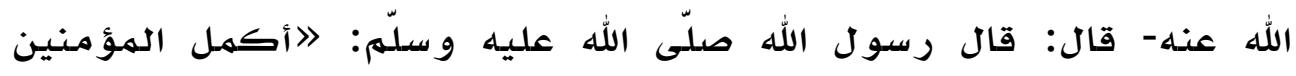

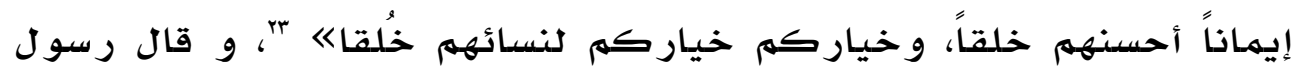

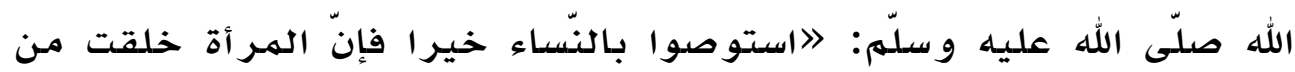

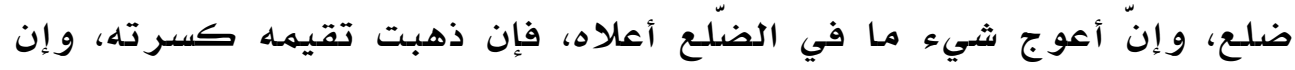

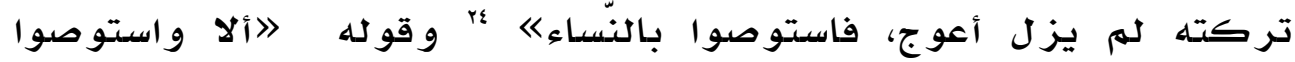

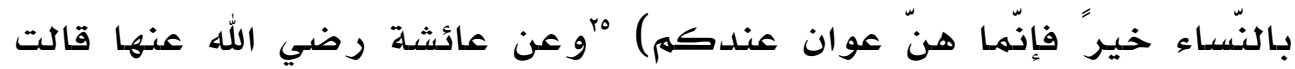
قال رسول الله صلى الله عليه وسلهم : (خيركم خيركهم لأهله و أنا خير كهم لأهلي) :

يعد العفو والصفح من القيهم السـامية التي حققها نبينا الكريهم عليه أفضل الصلاة والسلام وقد ذكرت ذلك السيدة عائشة رضي الله عنها عندما سئلت عن خلق رسول الله صلى الله عليه وسلهم، فقالت : (لهم يكن فاحشا

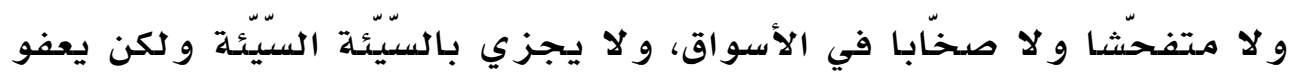
و ويصفح) 


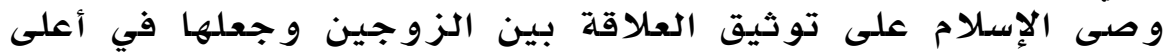

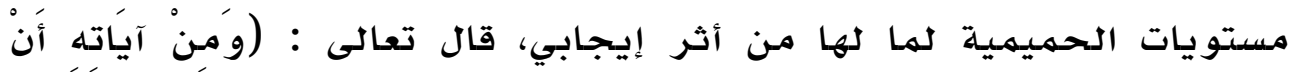

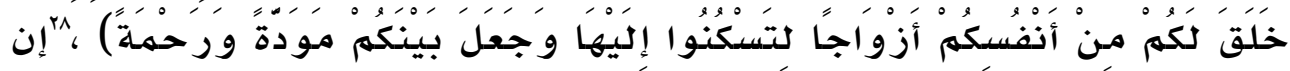

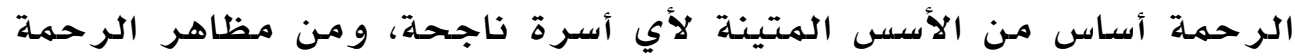

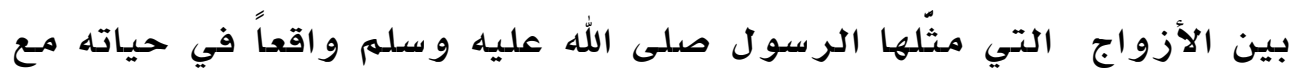

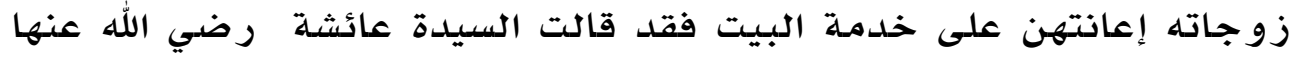
عندما سئلت عن ماكان يصنح الرسول على صلى الله عليه وسلهم في بيته قالت

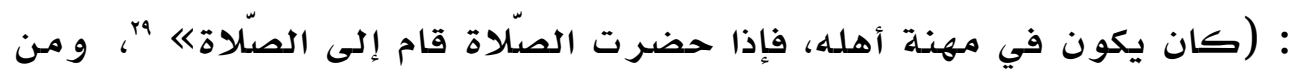

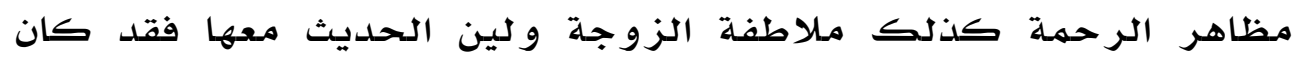

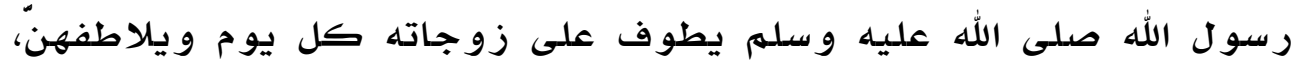

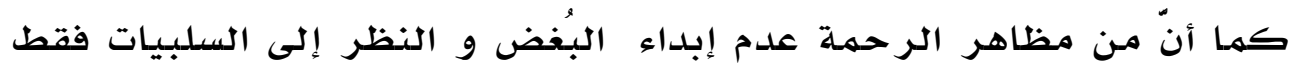

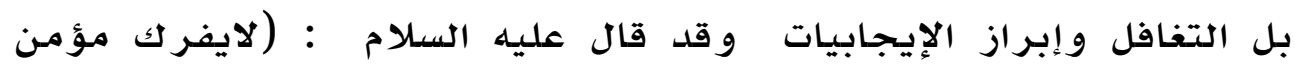

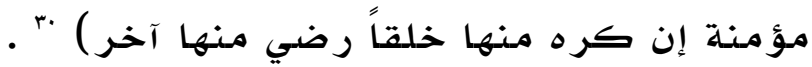

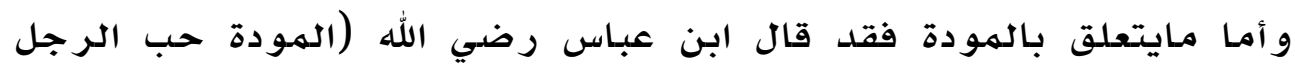

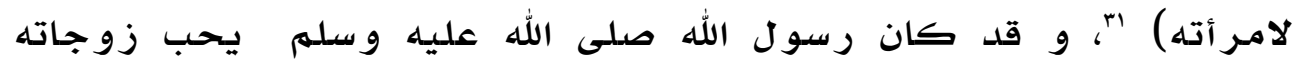

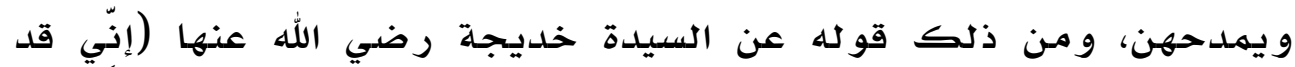

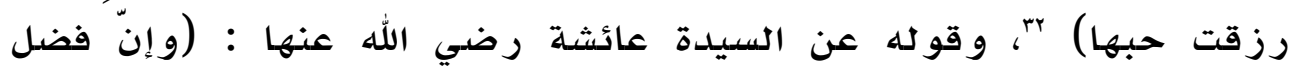

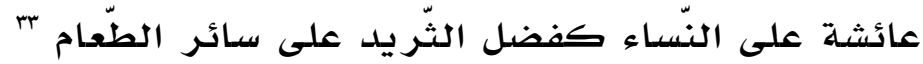

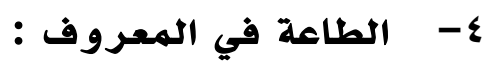
حث الإسلام الزوجة على أن تتودد إلى زوجها بطاعته والتزين

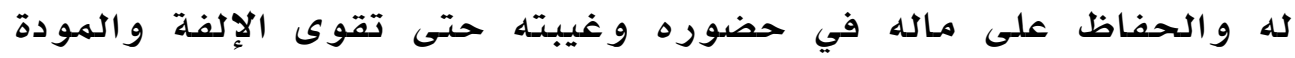

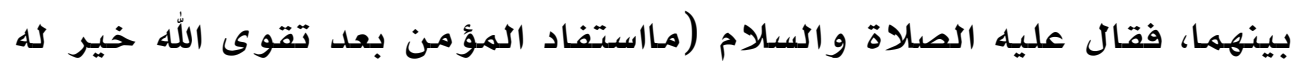
من زوجة صالحة إن أمرها أطاعته وإن نظر إليها سرته وإن غاب عنها

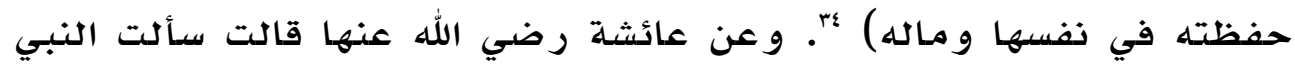

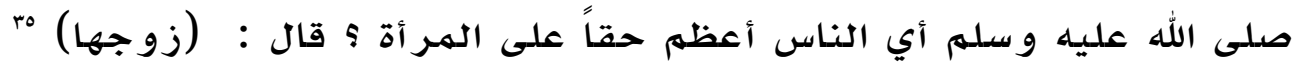

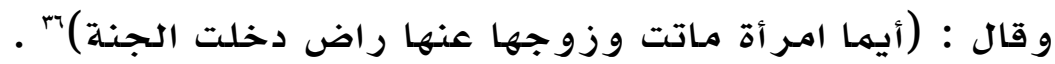


حث الإسلام على تحمل المسؤولية وجعل لكل فرد مسؤولية تجاه نفسه وتجاه غيره ينبغي عليه القيام بها و عدم التفريط فيها فقال رسول

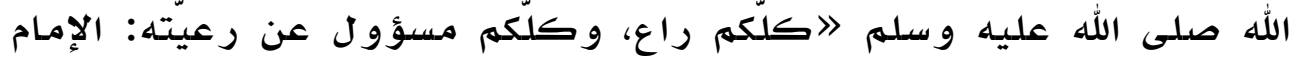

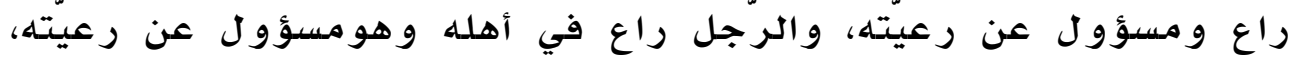

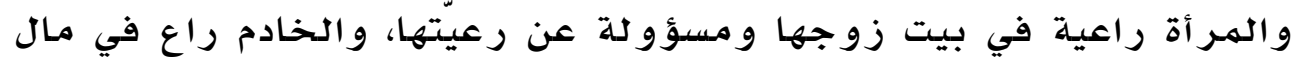

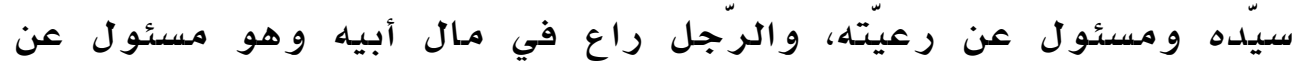

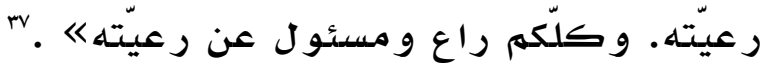

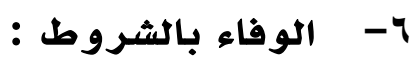

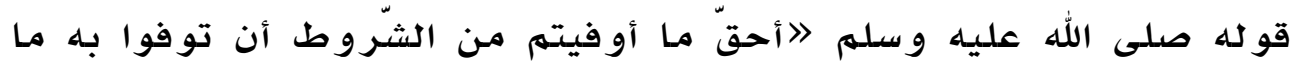

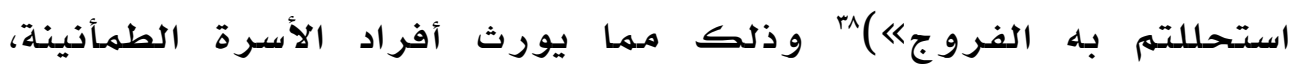

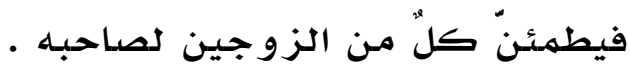

\section{- -V}

(عن أبي هريرة- رضي الله عنه- عن النّبّيّ صلّى الله عليه وسلّهم قال:

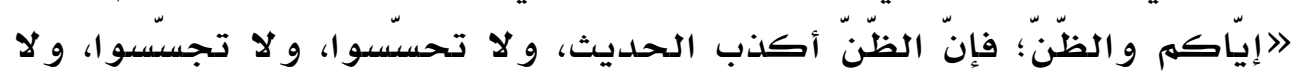

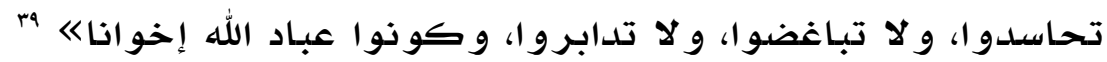

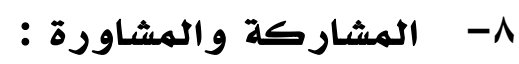
وذلك في أمور الحياة الزوجية القائمـة على التفاهم و والتشاور

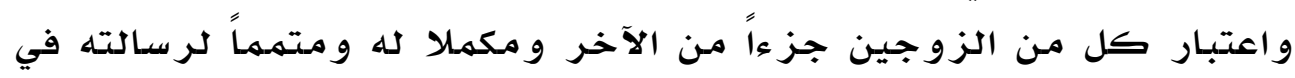

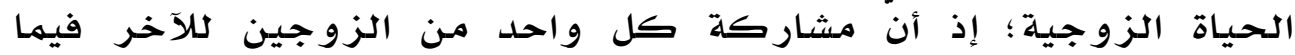

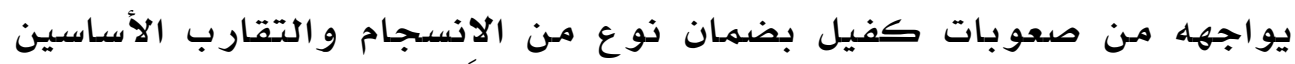

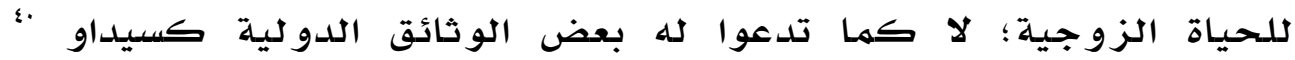

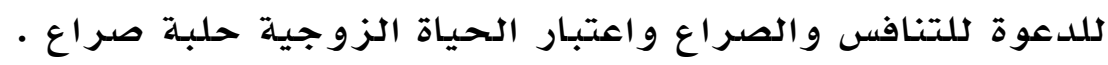

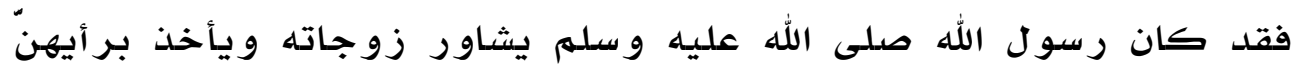

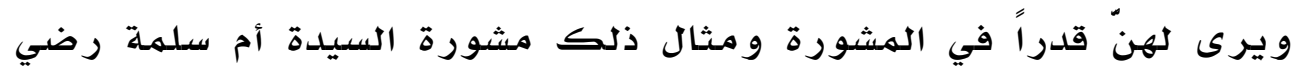

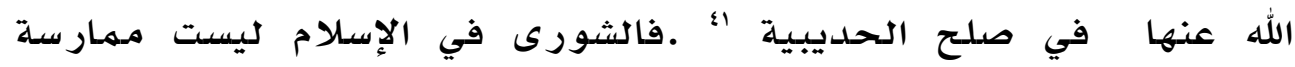

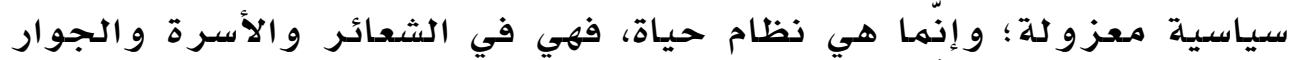


و المهجتهـع و الهعامـلات الاقتصادية و العلم و السياسـة بأ.

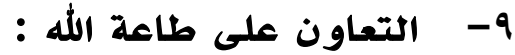

قال رسول الله صلى الله عليه وسلهم : (رحم الله رجلا قام مـن الليل فصلى، و أيقظ امـرأته، فإن أبت، نضتح في وجهها الهـاء، رحهم الله امرأة قامت مـن الليل فصلت، و أيقظت زوجها، فإن أبى، نضحت في وجهه الهاء.) بأ إذ أن أن أحب الزوجين لصاحبه أحبهها وأقربهما إلى الله .

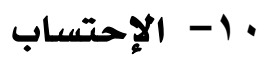

قو له صلى الله عليه وسلهم \إن الهسلهم إذا أنفق على أهله ذفقة، وهو

$$
\text { |رحتسبها، كانت له صدقة) ؛؛ العدل }
$$

من القيم التي اعتتى بها الإسـلام في الهـتمهع عموما وفي الأسـرة خصوصاً قيهـة العدل و من ذلك حرص الرسول صدلى الله عليه وسلهم على العدل بين زوجاته، ومـن ذلك أنَه إذا أراد سفراً أقرع بين زوجاته عن عائشةرضي الله عنها- زوج النبّيّ صلّى الله عليه وسلّهم- قالت: (كان رسول الله

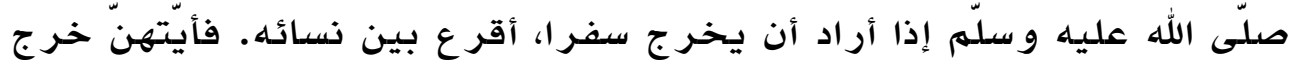

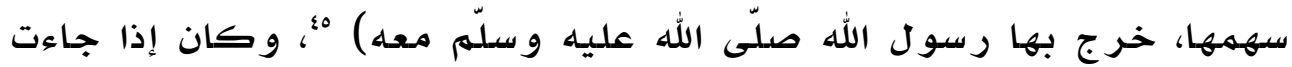

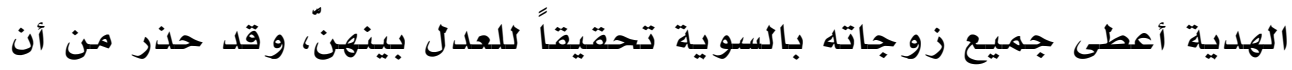
يحيف الرجل بين زوجاته فقال (من كانت له امر أتان فهال إلى إحداهما،

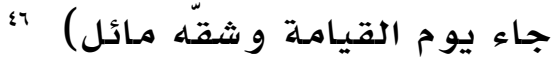

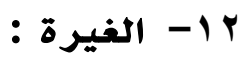

الغيرة المحهودة الهنضبطة تسـاعد على الحفاظ على الأسرة وضبط سلوك أفر ادها الأمـر الذي لا يتحقق في ظل اللامبالاة أو الغيرة الزائدة الغير منضبطة، فعن جابر بن عبد الله- رضي الله عنهما- قال: قال رسول الله صلّى الله عليه و سلّه: لارأيتني دخلت الجنّة، فإذا أنا بالرّميصاء: امـر أة أبي طلحة، وسمعت خشفة : فقلت من هذاء.فقال: هذا بلال.ور أيت قصرا بفنائه جاريـة، فقلت: لهـن هذاء فقال: لعهر.فأردت أن أدخله فأذظر إليه،

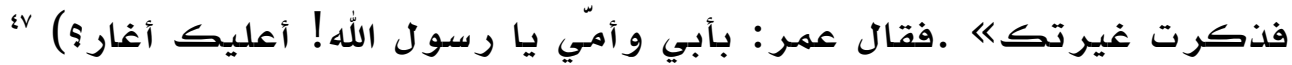




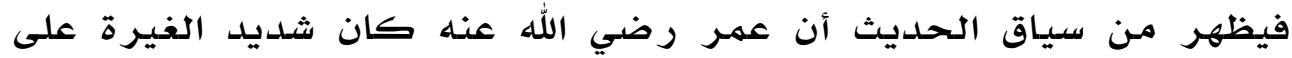

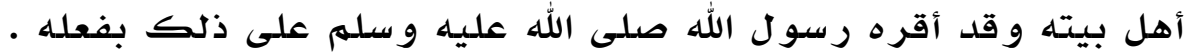
با

فقد نهي صلى الله عليه وسلهم عن نشر أسرار مايكون بين الأزواج حتي

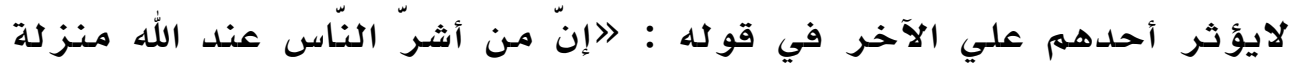

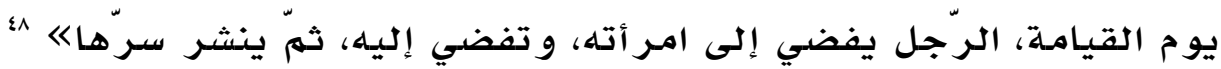

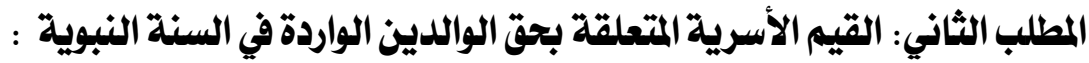

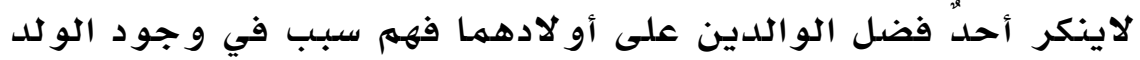

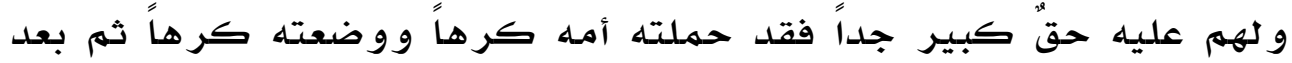
ذلك حضانة ورضاعة لمدة عامين من التعب و العناء و تعبت هي وو الده من

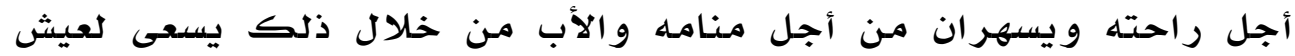

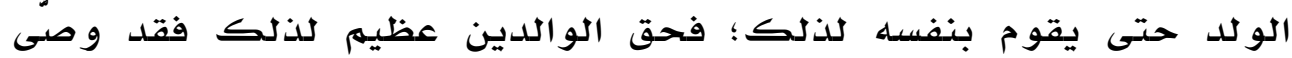

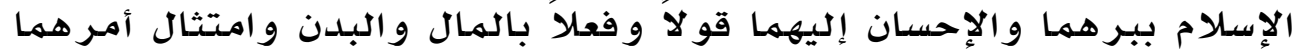

$$
\text { في غير معصيية }
$$

أتى بر الوالدين في المرتبة الثانية بعد الصدلاة في محبدة الله (عن عبد الله

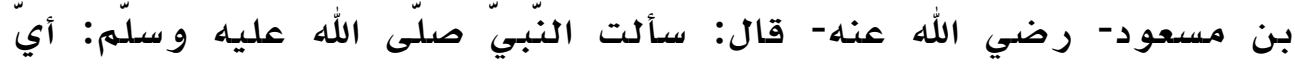

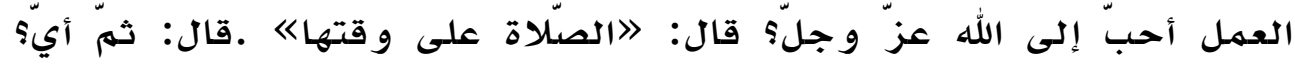

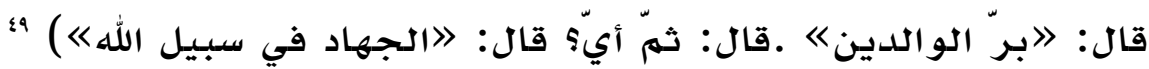

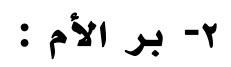

و من حرص الإسلام على مكانة الأم وتقييمهـ لها تقوم بـه أن منحها مزيدا

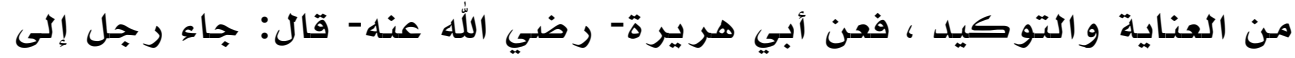

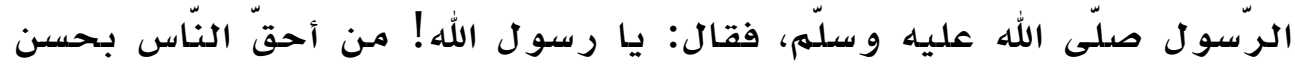

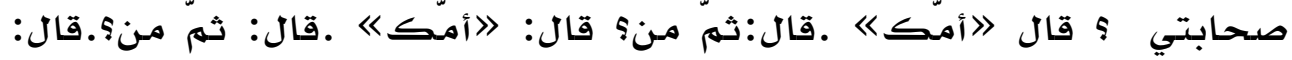

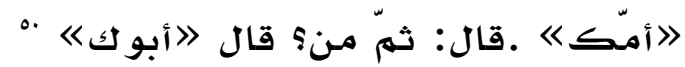

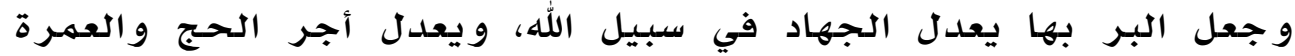

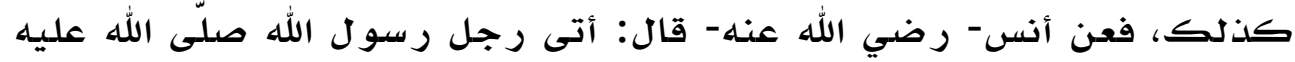

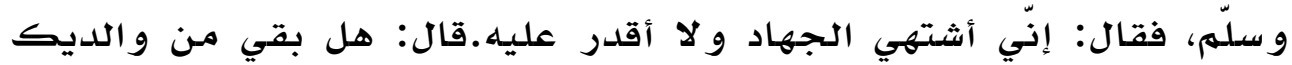


أحدى قال: أمي. قال: لاقابل الله في برها فإذا فعلت ذلك فأنت حاج

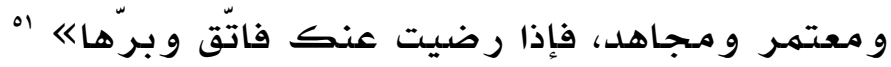

ب- بر الوالدين بعد و فاتهما :

و منن عناية الإسلام بالوالدين أذه جعل برهما يتواصل حتى بعد و فاتهما،

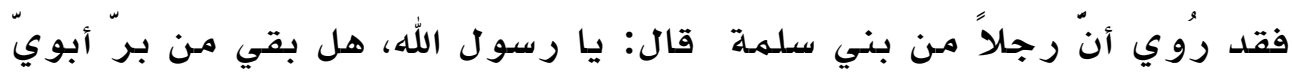

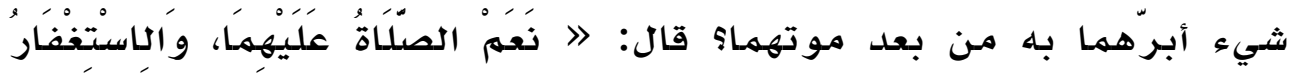

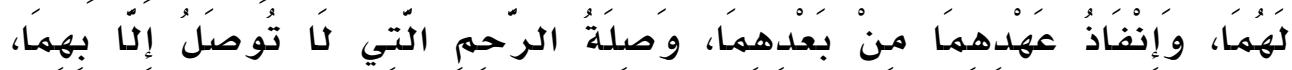

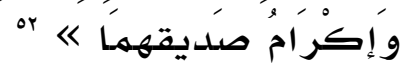

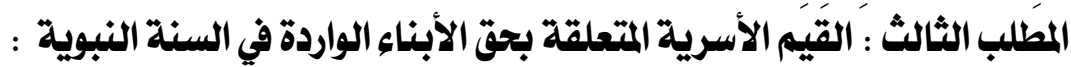
تمثل الأسرة محضن الطفل وبيئته الطبيعية الكلازمهة ذرعايته وتربيته وهي الهدرسة الأولى التي ينشأ الطفل فيها على القيهم الإنسـانية والأخلاقية

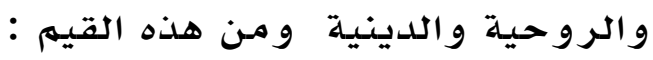
ا- العدالة في المعاملة : و يشهل ذلك العطاء و الحنان و الكلهمة الطيبة، فعن النعمهان بن بشير - رضي الله عنهما- اأنّ أمسّه بنت رواحة سألت أبـاه بعض الموهوبـة مـن مـاله لابنها فالتوى بها سنة، ثمّ بدا له، فقالت: لا أرضى حتى تشهد رسول الله صلّى الله

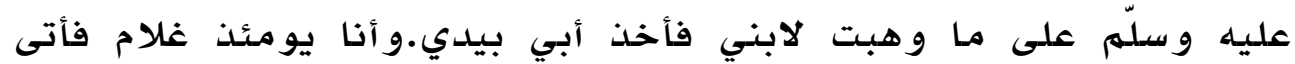

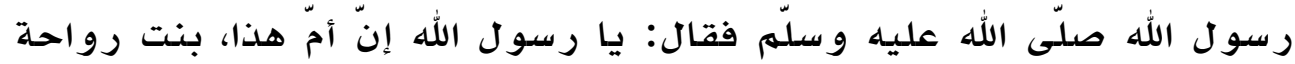
أعجبها أن أشهدك على الّذي وهبت لابنها.فقال رسول الله صلّى الله عليـ الله

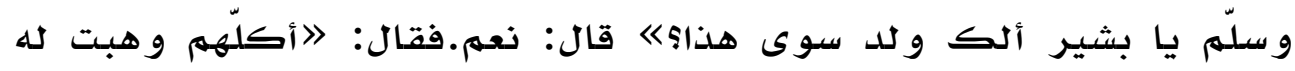

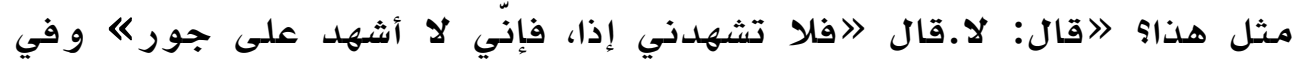

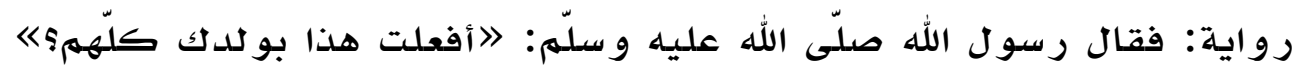

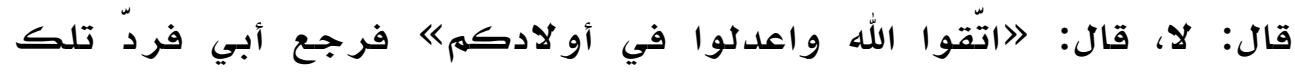
الصدّلدقة )

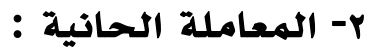

عن أبي هريرة- رضي الله عنه- قال: قبّل رسول الله صلّى الله عليه و سلّهم

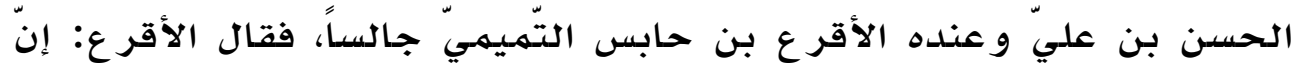
لي عشرة من الولد ما قبّلت منههم أحدا.فنظر إليه رسول لـو الله صلّى الله عليه 


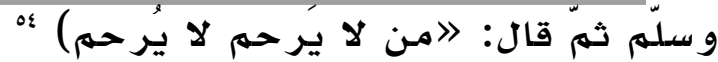

$$
\begin{aligned}
& \text { r- حسن اختيار البيئة لتربيتهما : }
\end{aligned}
$$

و ذلك بالتو صيية على حسن اختيـار الزوجين و ذلك لتهيئة بيئة صالحة للموولود مستقبـلاً (عن أبي هريرة- رضي الله عنـه- قال:قال رسول ل الله صلّى

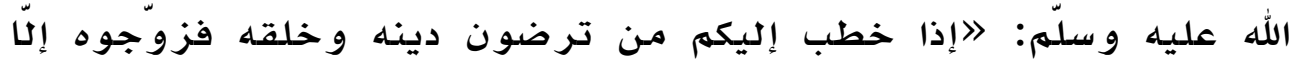

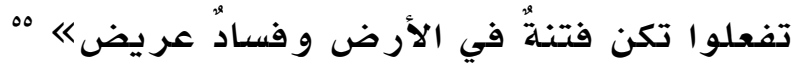
(عن أبي هر يرة- رضي الله عنـ- عن النبّيّ صلّى الله عليه وسلّم قال: التنكح الهر أة لأربع : لها لها، و لحسبها ، و لجمالها، و لدينها.فاظفر بـذات

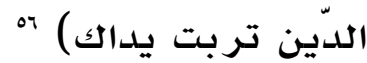

و قو له عليه الصدلاة والسلام : (تخيروا لنطفكه و انكحوا الأكفاء و أنكحوا ov (إليهم)

ع- أن يحسن أدبه ويعلمه أمور دينه و ذلك بتعليهمه قواعد الإيهمان وتلدريبـه على عبـادة الله وطاعته و تأديبـ بآداب الإسلالام وومكارم الأخلاق

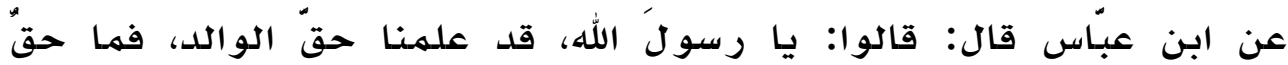

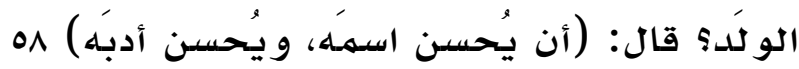

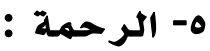
قو له صلى الله عليه وسلهم : (ليس منا من لهم يرحمّ صغيرَنا، ويعرف حق

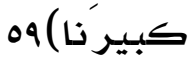


المبحث الثالث : أثُر القيم الإسلامية في الاستقرار المجتمعي و الأسري .

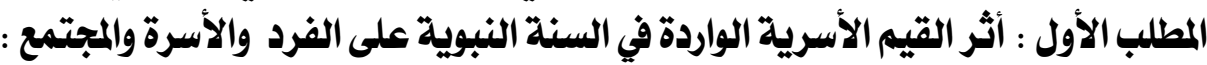

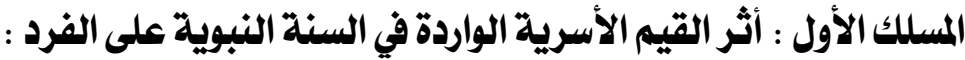

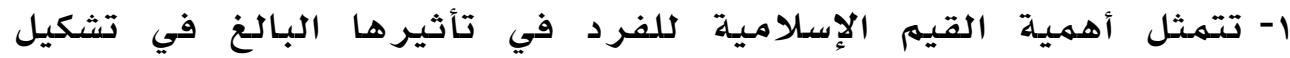
سلوكه وبناء شخصيته و تعريفه بذاته، فبالقيم يُصير الإنسان إنساناً

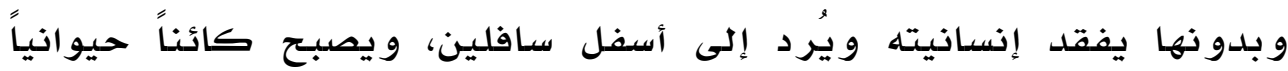

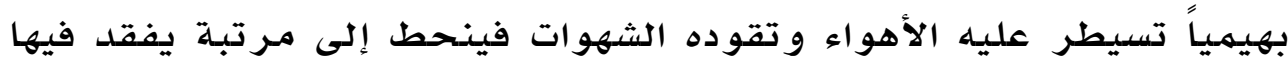

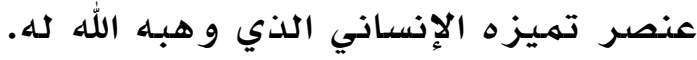

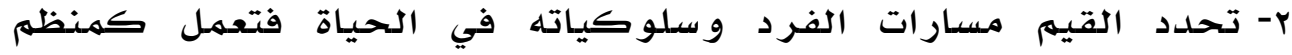

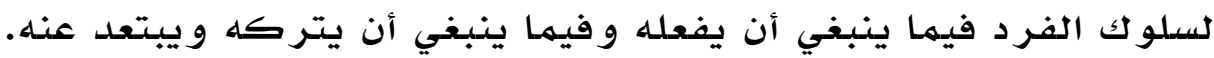

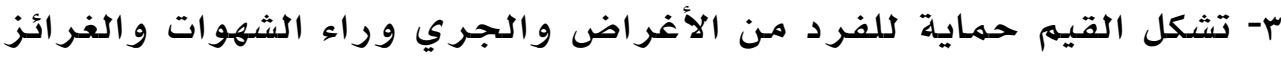

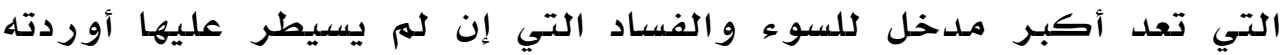

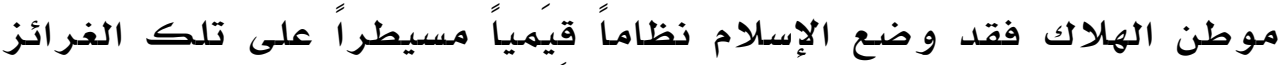

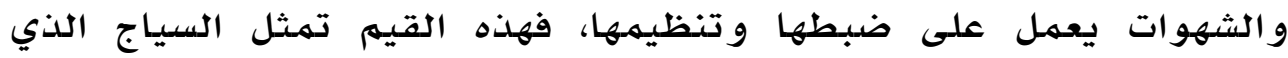

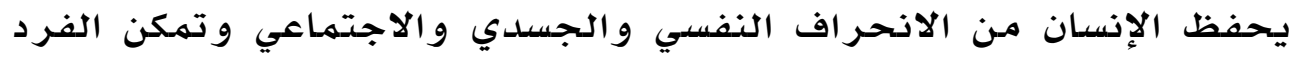

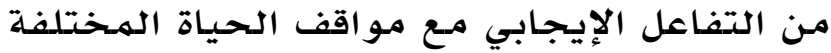

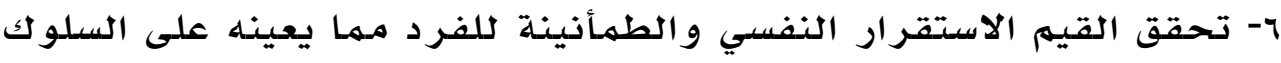

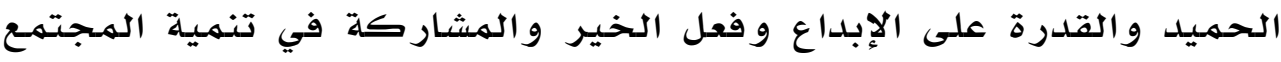
و تطو يره المسلك الثاني : أثر القيم الأسرية الواردة في السنة النبوية على الأسرة:

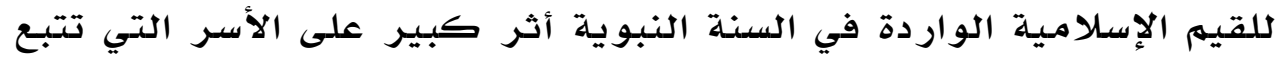

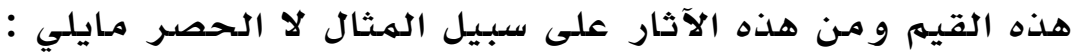

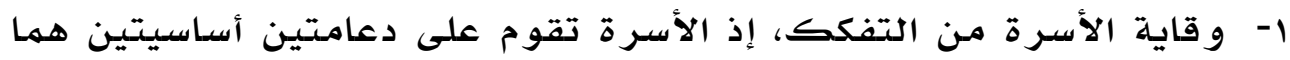

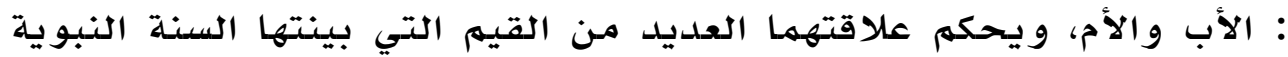

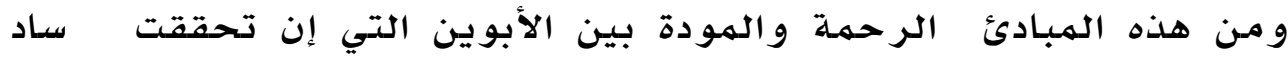

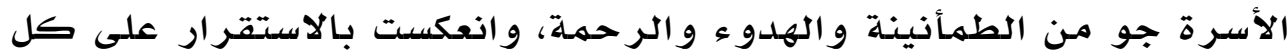

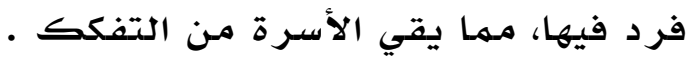

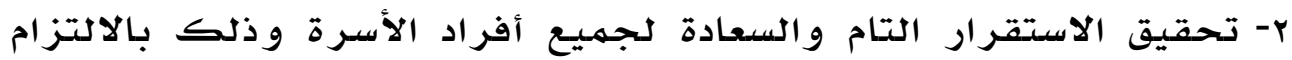


بالقيم الاسلامية في الأسرة كحسن الهعاملة وحسن الخلق .

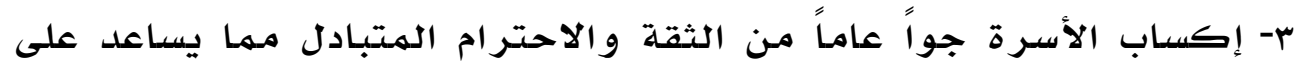

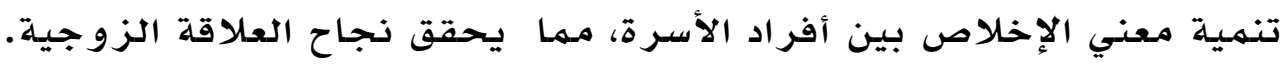

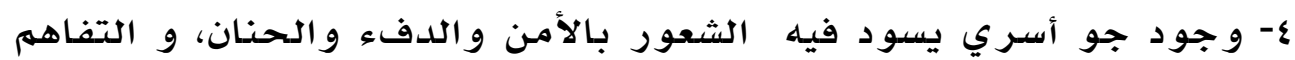

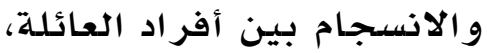

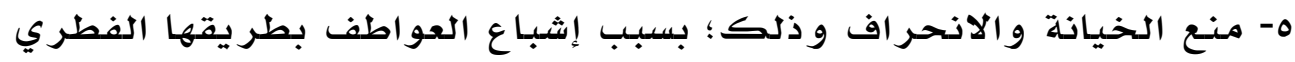

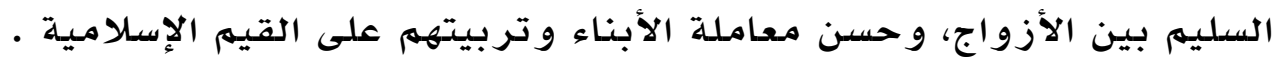

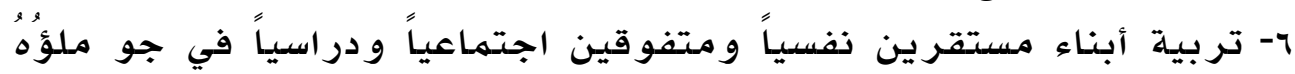

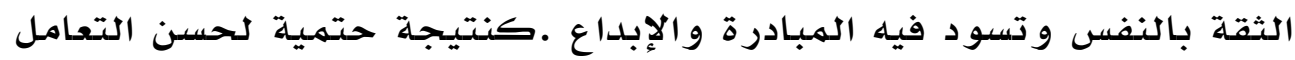

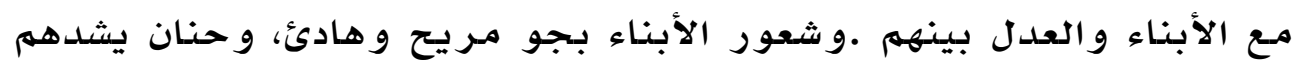

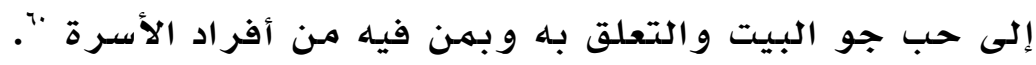

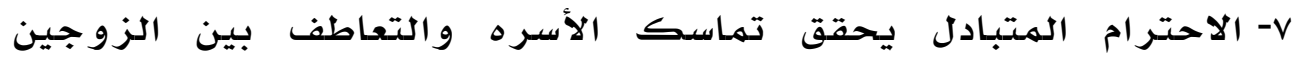

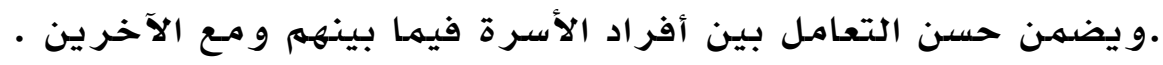

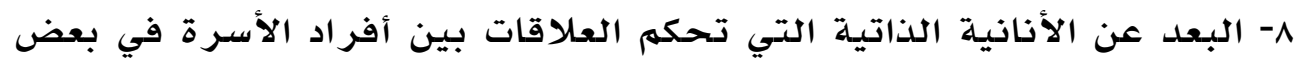

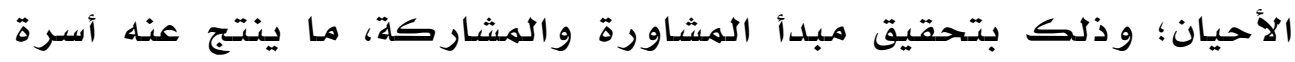

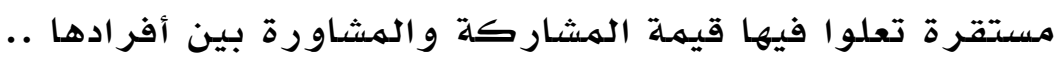

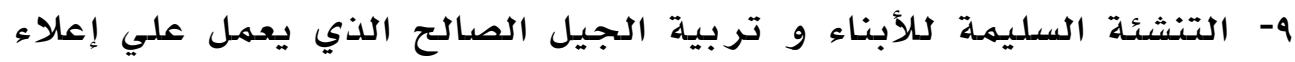

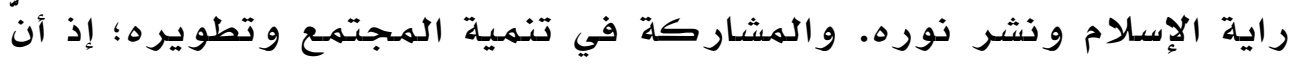

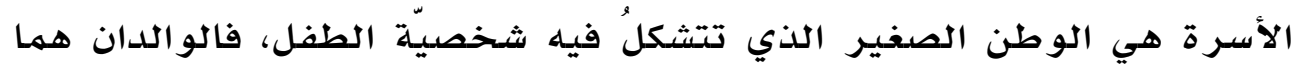

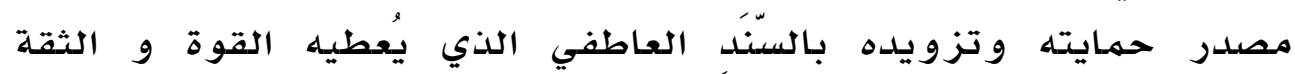
و السـلامهة النفسية.

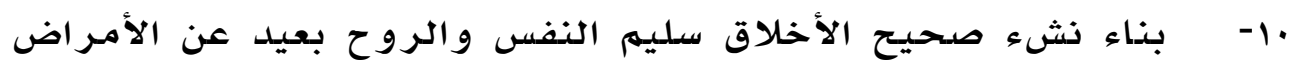

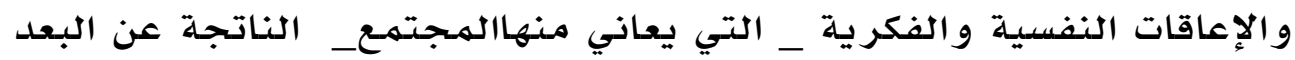
عن القيه الإسـلامية

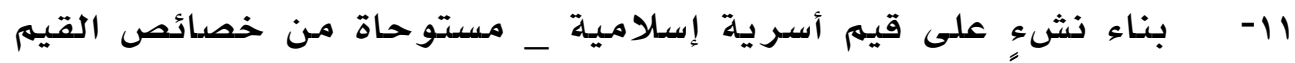

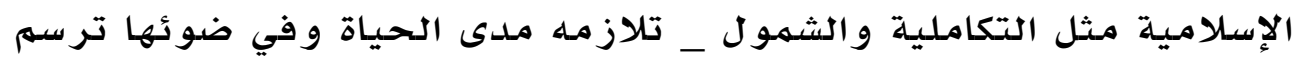

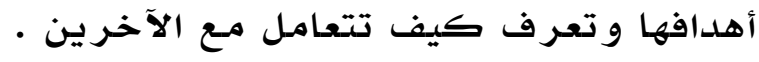




\section{المسلك الثالث : أثُر القيم الأسرية الواردة في السنة النبوية على الأمة والمجتمع}

للقيهم أهميـة بالغة في حياة الشعوب حيث إذها تحفظ للهمتهـع بقاهه و استهـر اريته. فقوة الهـتهـع وضعفه لا يتحدد بالهعايير الهادية وحدها بـل إن" معيار و وجودها واستهمراريتها مـرهون بها تمتلكه مـن معايير قيهيـة و خُلقية.

و في حالة اختلال الهوازين وفقدان البناء القيمهِي السليهم يؤول بـالهـجتهـع إلى الضعف والتفكك والانهيار و تتفشى فيه الأمراض الاجتهماعية، وقد أثبت التاريخ الإنساني ذلك، حيث زالت حضارات بشرية كانت مثالاً في القوة والسيطرة والهيهنة فزالت عندما تفشى فيها الظلهم وساد فيها فساد القيه و الأخلاق. وقد وضح القر آن الكريه هذه الحقيقة في عديد من آياته التي جاءت تعقيبا على نهاية أقوام وومستمعات رفضت معايير القيهم الفاضلة وركنت إلى معايير فاسدة وانحلال أخلاقي و اجتهماعي، فاستحقت بفعلها وسلواه كها

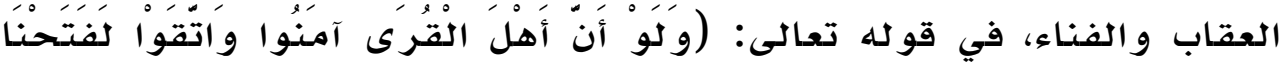

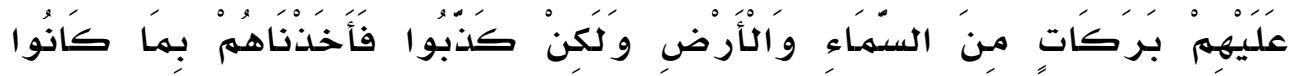

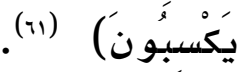

القيهم تحفظ للهمجتهـع هويته وتهيزه، فالحفاظ على هوية الهـتهـع تنبع من الهمحافظة على معاييره القيميلة الهتأصلة لدى أفراده، فإذا تزعزعت هذه القيم أو اضهحلت فإنٍ ذلك دليل على ضعف الهوية الهميزة إن القيم تحفظ الهـتهمع مـ السلوكيات الاجتهاعية والأخلاقية الفاسدة، فتؤمسن له حصناً راسـخاً مـن السلولك و القيهم والآخلاق التي تحفظ

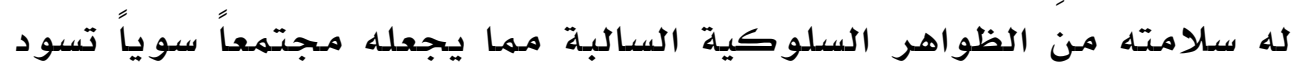
فيه قيهم الحق و الفضيلـة و الإحسان وتحارب فيـ قيهم الشر و الفساد. وهنا تبرز أهمية البناء القيمي السليهم لـلأفراد حيث يتهكنون من التمييز بين الخير والشر، وبين النافع والضار وفق معايير الثقافة التي يؤمنون بها، و هذا مـا يجب أن تقوم بـه وسائط نشر القيهم الفاضلة والتي تتمثل في 
الأسرة و الهسسجد و الهـدر سـة(r).

ويهكنـا أن نجمل القول في أن تطبيق القيهم الأسـرية التي وردت في السنـة

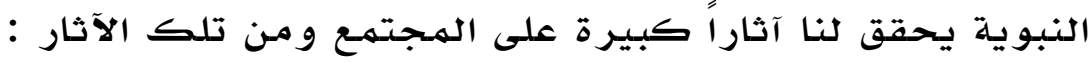
ا- الهساعدة على نجاح الأمّة في مسير تها. وذلك بأن ينهض كلّ من

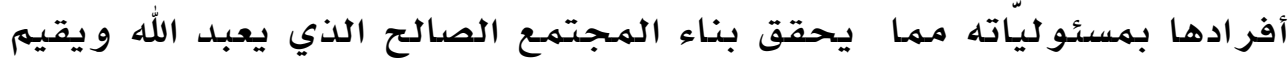
حلدو ده.

ץ- الحصدل على علاقات اجتهاعية قوية، وتحقيق الترابط والانسـام بين أفر اد الهـجتهـع، ب- إيجاد قاعده قويه مـن أفراد الأمـة الإسـلاميـة التي تلقي علي عواتقههم استعـادة مـجد الأمـة. ع- حماية الهـتهمع مـن الظواهر السـالبة الناتجة عن البعد عن القيهم

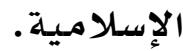

ه- الحدّ من النز اعات و الخلاففات، وذلك لشيوع المودة والرحمة و - الاحتر ام في الهـجتهـع צ- تكون السيادة لهكارم الأخلاق التي تهثلها الرسول الكريهم في حياته العهلية و أو صى بها صحابته الكر ام و مـن بعدهم . V- تكوين مستهـع مثالي يسعى إلى تكوين أمهة مثالية ذات حضارة قوية و فاعلة الاطلب الثاني :أثر القيم الأسرية الواردة في السنة النبوية على حل المشكلات : المسلك الأول : الوقاية من المشكلاتئ قبل وقوعها : بالتأمل في سيرة الرسول صلى الله عليه وسلهم و مـاأمـر بـه ونهى عنـه نجد أنذه خط لنا منهجاً وقائيا لهنـع الوقوع في المشكلات يتمثل في : ا- معرفة أفراد الأسرة للحقوق والواجبـات و الإلتز ام بها . ץ- النهي عن نشر أسرار مـايكون بينهما لقو له صدلى الله عليه وسلـم (إنّ من

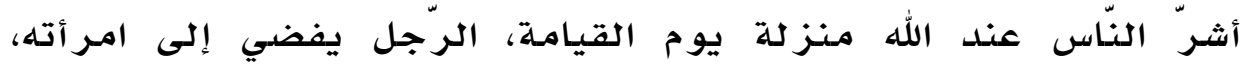

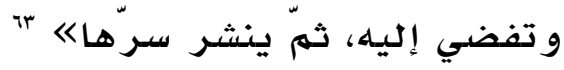

ب- الحر ص على البعد عن إظهار الخلاف _ _ إن وجد _ بعيداً عن الأطفال و عدم إثـاعته بين الأهل و المعارف . 
ع- أن يحث كل" من الزوجين الآخر على تقوى الله .

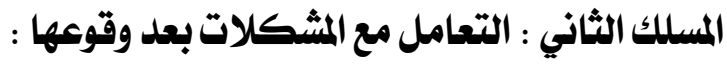

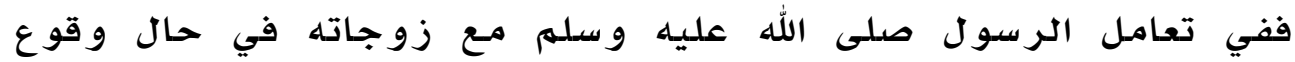

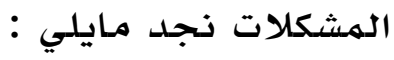

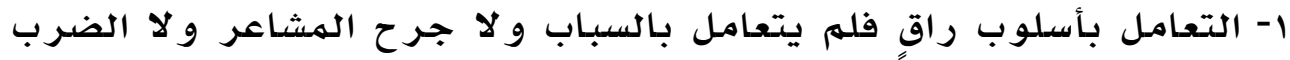

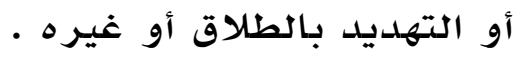

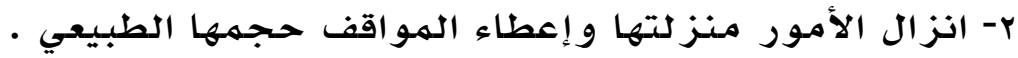

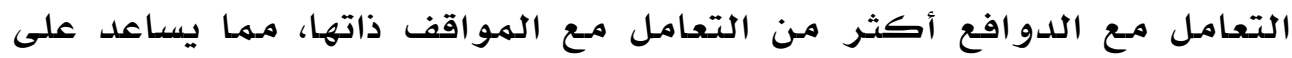

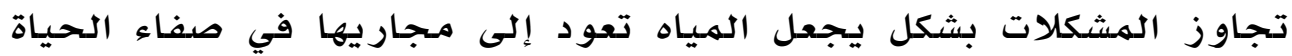

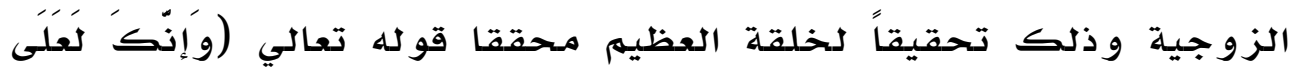

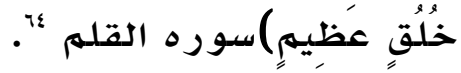




\section{الخاتمة : (النتائج والتوصيات):}

أولاً : النتائج :

ا- الأسرة هي أساس الهـتهمع و باستقر ارها واستمـر ارها يتماسك الهجتهمع كله و بتفككها يتمـزق المـجتهـع ويفسلد.

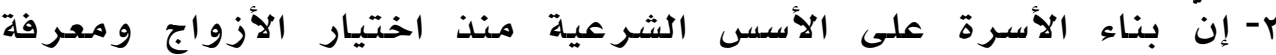

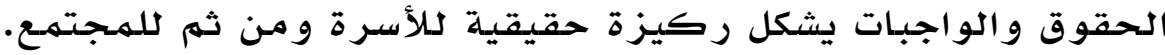

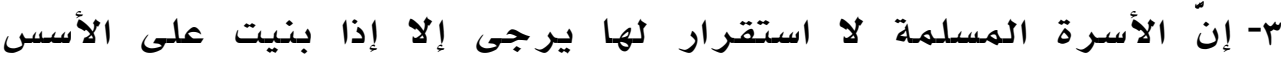

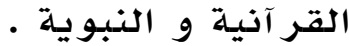

ع- تعتبر القيهم الحميدة من خلال القر آن الكريمم و السنة النبوية

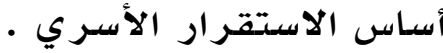
ه- إن" بناء الأسرة على القيم الإسلامية كهما وردت الأل في السنة النبوية يضمن لها الاستقرار ويضمن وجود جيل قوي معتز بدينه مستعد لتحمل

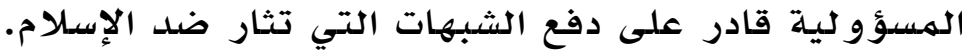

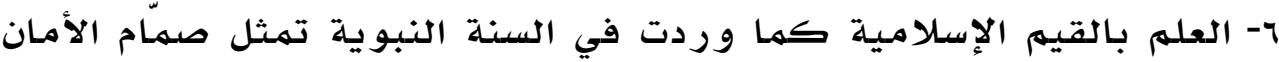

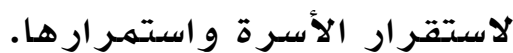

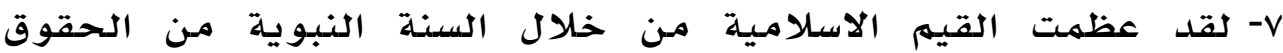

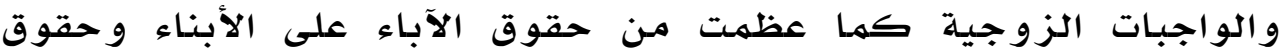
الأبناء على الآباء و صلة الرجات الرحم. ^- مـن أعظه القيه الإسدلامية مـ خلال السنة النبوية قيمة حسن الخلق و حسن المعاملة .

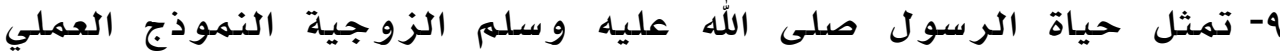

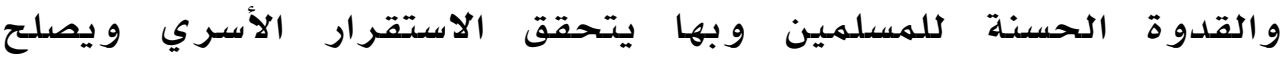

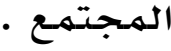

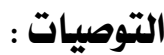

ا- تعظيه الأسرة من قبل الأمسة لأنها تمثل الحصن الآمـن للأمـة، وذلك بهعرفة القيم من خلال السنة النبوية وومن ثم تطبيقها في الواقع . r- الحرص على بناء الأسرة على القيه الإسلامية كما وردت في السنة النبو يية 
ب- التعريف بالقيم الإسلامية عبر و سـائل الاعلام ووسائل التو اصل الاجتمـاعي و منـاهـ التعليهم وعبر منظمات الهـجتهـع الهـدني و مؤسسـات اللدعوة .

ع- التعر يف بحياة الرسول صلى الله عليه وسلهم الزوجية كلاقتداء والاهتداء - بها

ه- تدريب الهقبلين على الزواج على تكوين الأسـرة السعيدة وذلك من خلال :

أ- تطبيق هذه القيهم عبر دورات حتهيـة للتأهيل للحياة الزوجيـة السعيدة ب-التعريف بهـهـج الإسـلام في التربية الرشيدة لـلأبنـاء . ت-التعريف بهنهج الرسول صلى الله عليه وسله في حل المشكلات الأسـر يـة. 


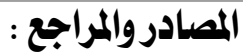

أولاً : الإصادر : آماد

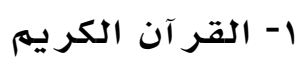

r- كتب السنة النبو ية

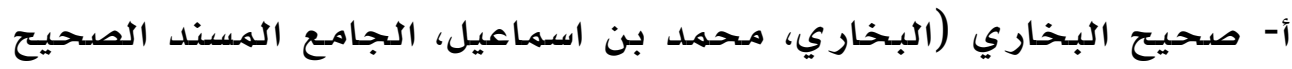

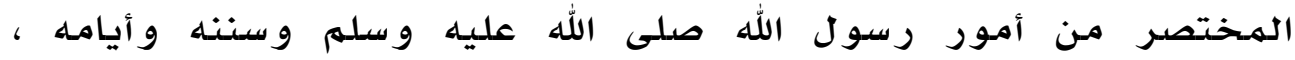
الهحقق: محمد زهير بن ناصر الناصر، الناشر: دار طوق النجاة، ط له (هI I rr

ب-صحيح مسلم (مسله بن الحجاج، المسند الصحيح المختصر بنقل العدل

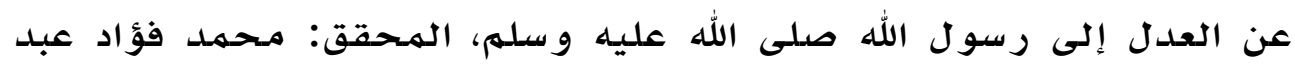

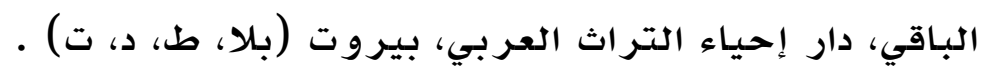

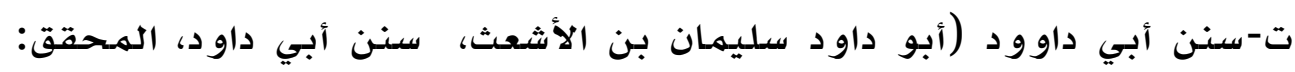

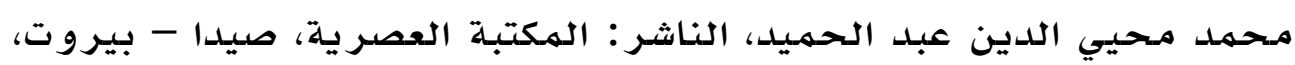

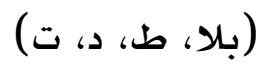

ث-سنن التر مذي (التر مذي، محمدل بن عيسى، الجـامع الكبير سنن التر مذي،

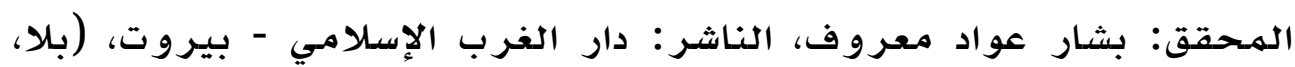

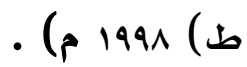
ثانياً : المراجع :

ا- البهي، فؤاد السيد، علهم النفس الاجتماعي ، الناشر دار الفكر العربي القاهرة، طا، 1999 . 199 ץ- بني خالد، حسن طاهر، فن التدريس في الصفوف الابتدائية، دار أسامـة

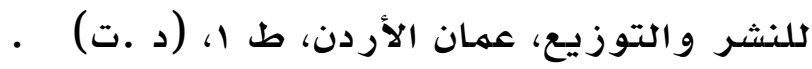

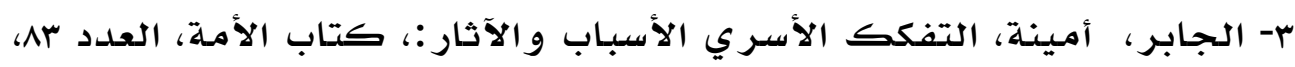

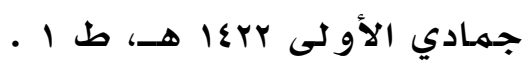

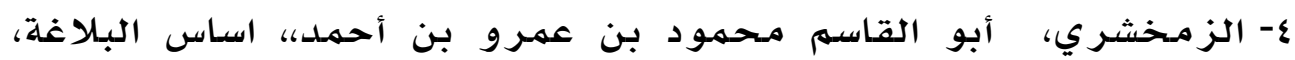

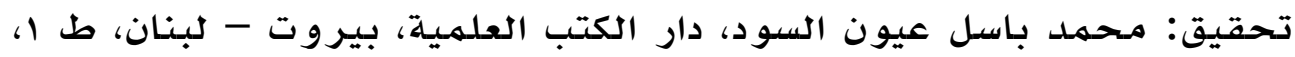
- 1991 - 1 1 1919 
ه- السباعي، مصطفى، السنة و مكانتها في التشريع الإسلامي،دار الوفاق

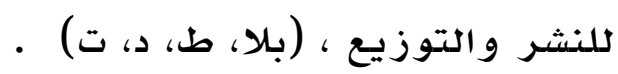

צ- عبد الرحمن أحمد عثمان، الإرشاد الزواجي، دار، دار أفريقيا العالميلة -

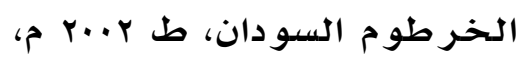

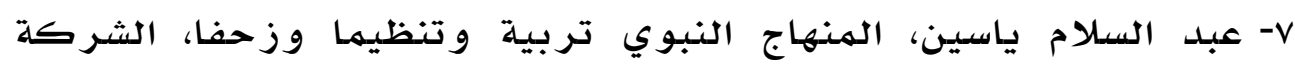

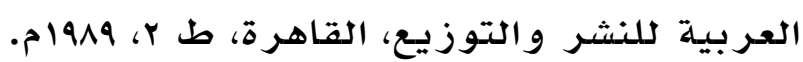

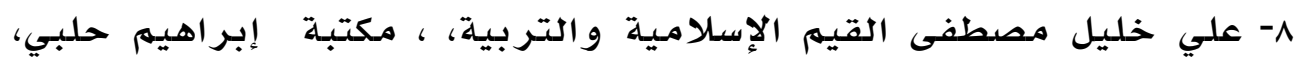

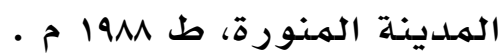

ه- الفيروز آبادي، مجد الدين محمدد بن يعقوب، القاموس الهحيط، تحقيق:

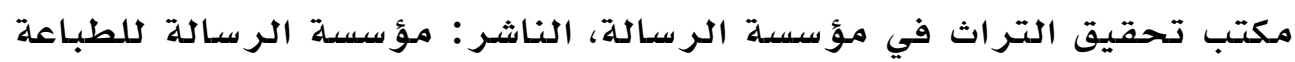

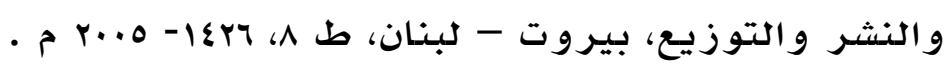

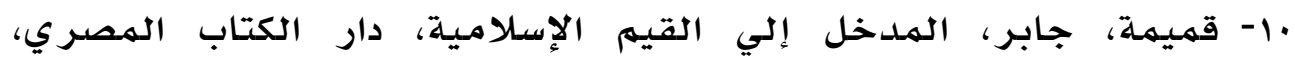

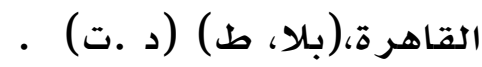

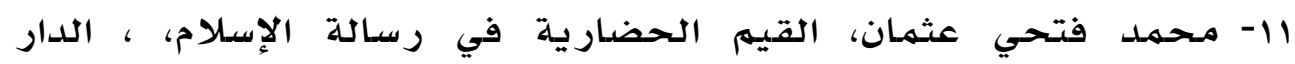

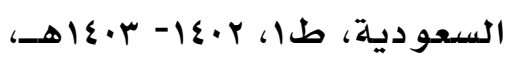

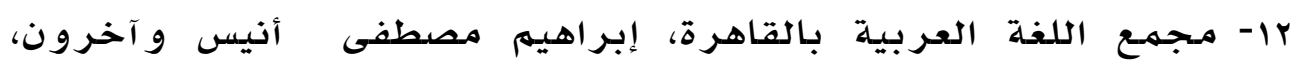

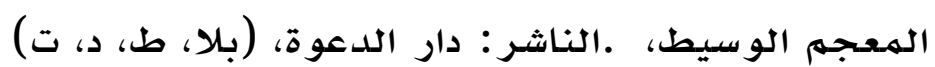

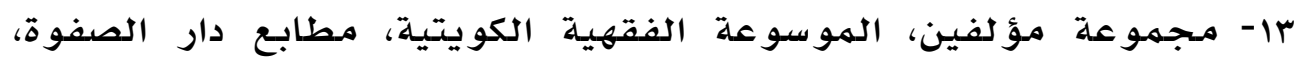

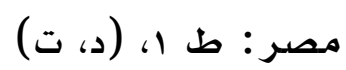

عا- مجموعة من المختصين، موسوعة نضرة النعيه في مكارم أخلاق

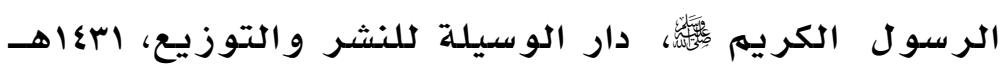

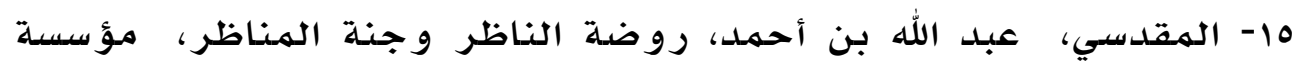

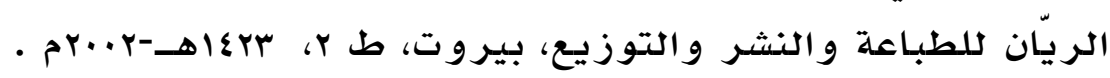




\section{الهوامش}

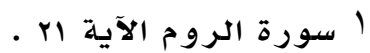

ץ أمينـة الجابر ، التفكك الأسري الأسبـاب والآثار: ، كتاب الأمهة ، العدد به الأه ، جمادي

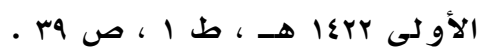

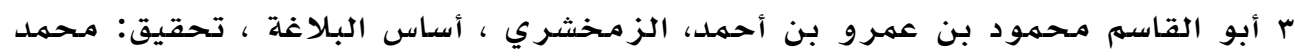

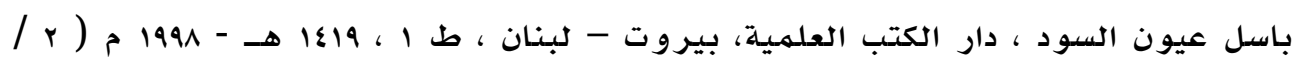
. (rIr

عمجد الدين محمدد بن يعقوب الفيروز آبادي ، القاموس الهـيط ،تحقيق: مكتب تحقيق

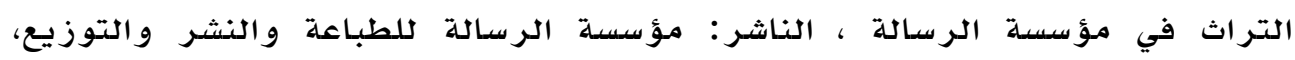

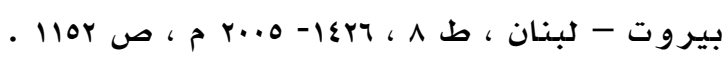
ه) فؤاد البهي السيد ، علم النفس الاجتماعي ، الناشر دار الفكر العربي - القاهرة ، طا، . $9 \varepsilon$ ، 1999 جعلي خليل مصطفى القيم الإسلامية والتربية ، ، مكتتبة إبر اهيم حلبي ، المدينة

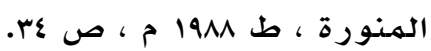

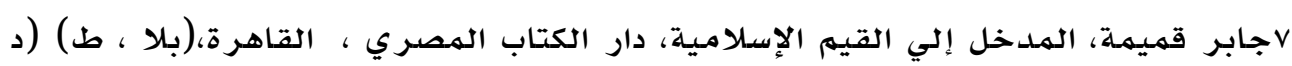

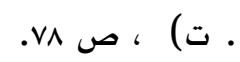

^ حسن طاهر بني خالد ، فن التدريس في الصفوف الابتدائية ، دار أسامـة للنشر

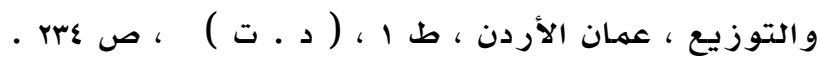

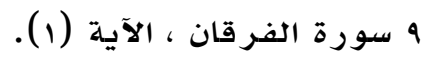

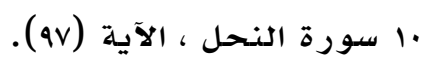

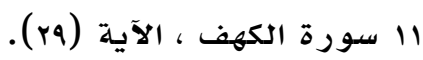

rامجموعة من المختصين ، موسوعة نضرة النعيم في مكارم أخلاق الرسول الكورة الكريم . . .

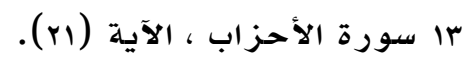

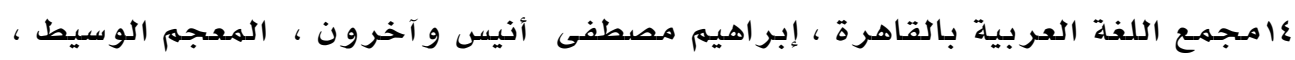

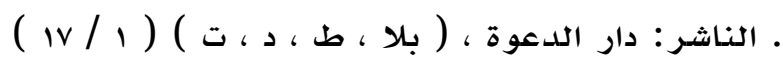
- 10 Tا عبد الرحمن أحمد عثمان ، الإرشاد الزواجي ، دار أفريقيا العالمية - الخرطو الهوم

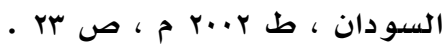

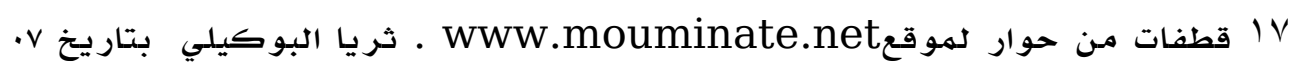

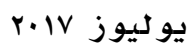




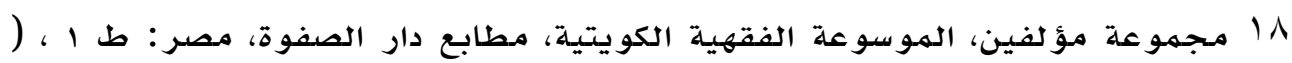

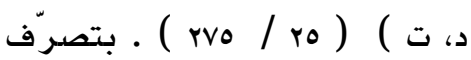

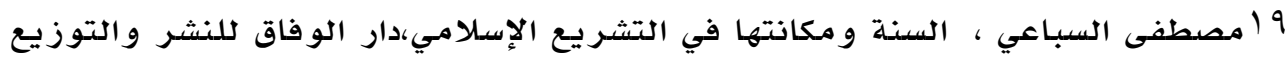

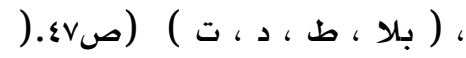

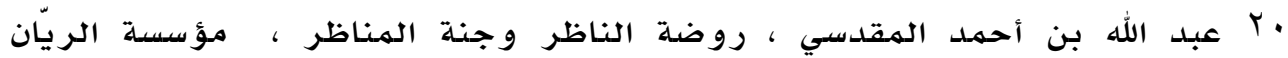

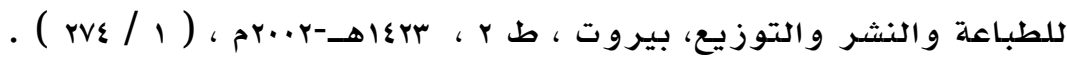

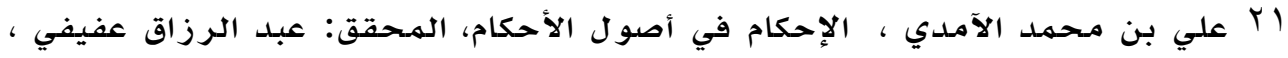

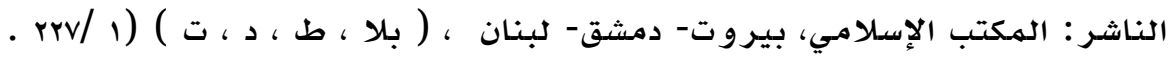

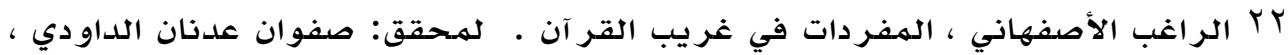

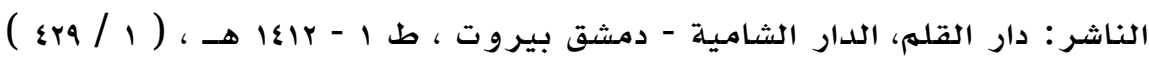

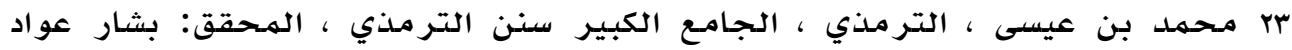

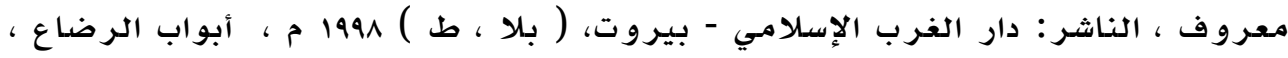

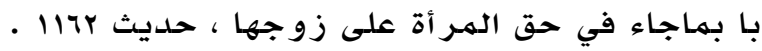

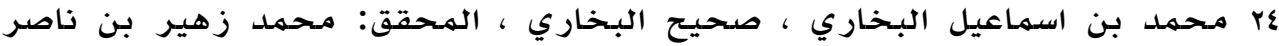

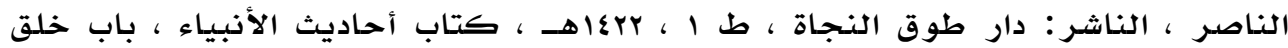

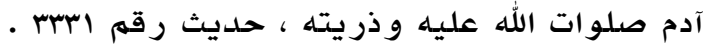

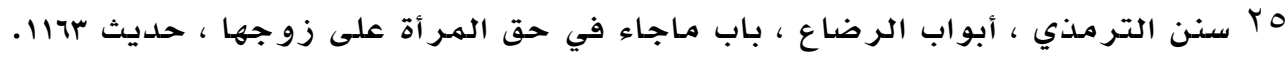

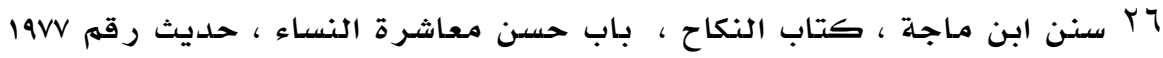

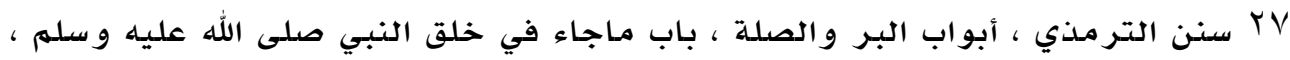

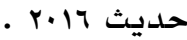

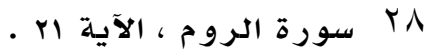

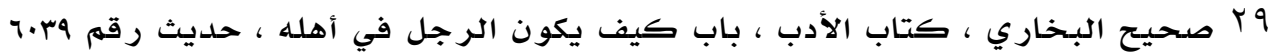

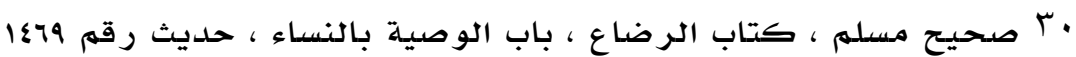

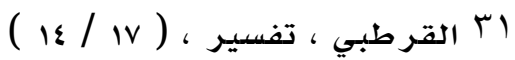

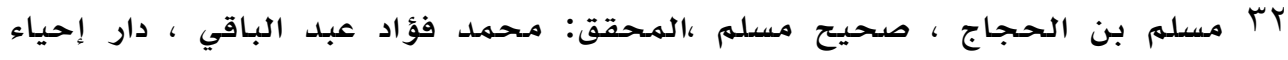

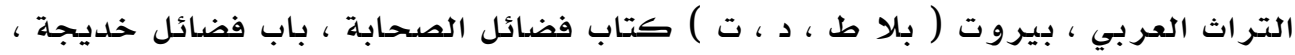

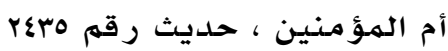

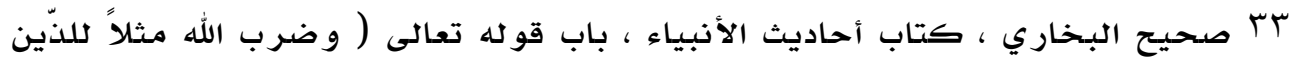

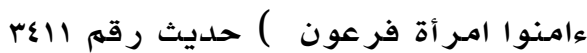

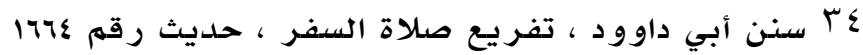

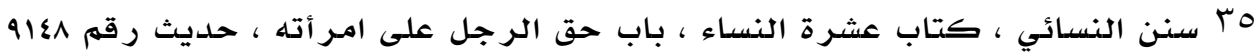


جب سنـن ابن ماجة ، كتاب النكاح ، باب حق الزوج على المر أة ، حديث رقم عهما

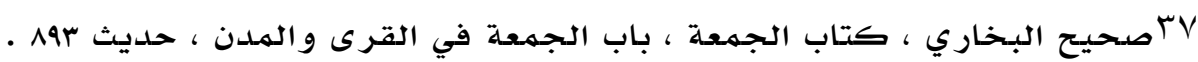

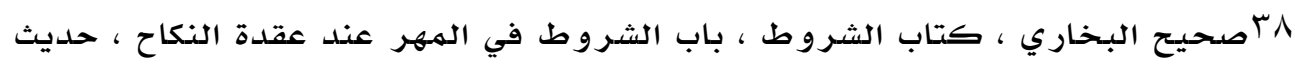
• رقم

وس صحيح البخاري ، كتاب النكاح ، باب لا يخطب على خطبة أخيه ، حديث رقم

•ع اتفاقية مكافحة جميع أشكال التمييز ضد المـر أة، وهي اتفاقية دولية تدعو للمساواة

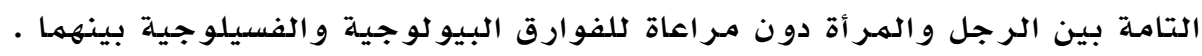

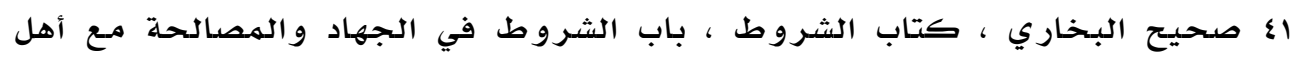
الححرب ، حديث رقم

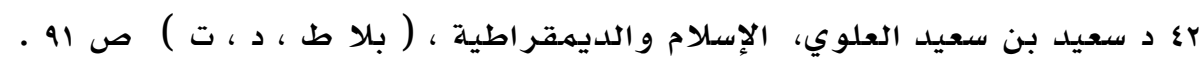

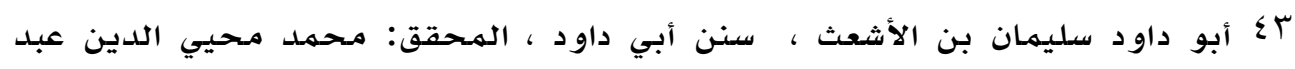

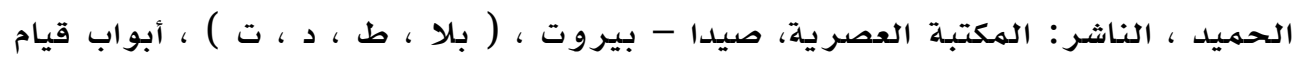

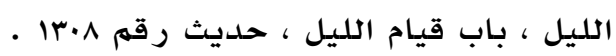

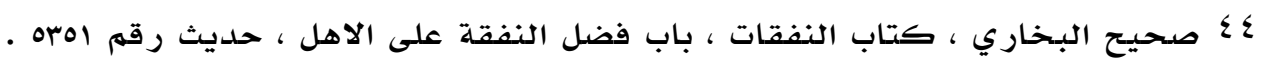

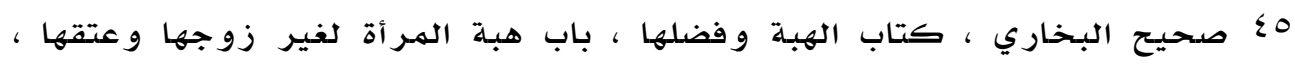

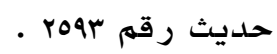

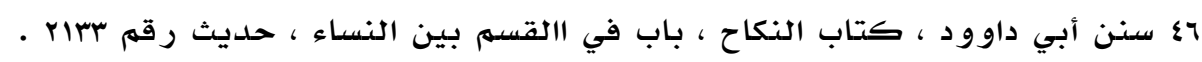

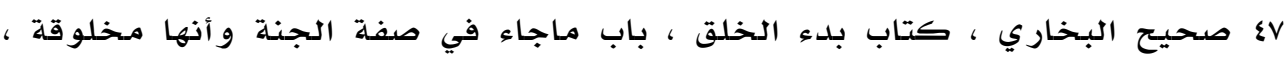

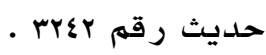

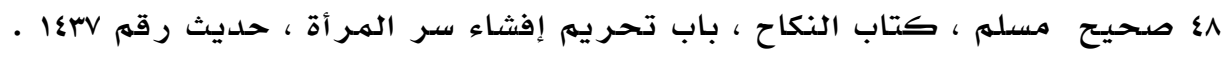

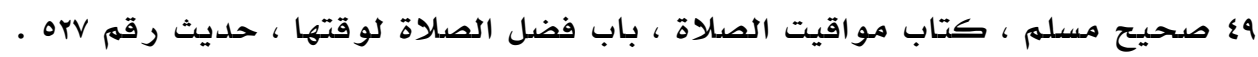

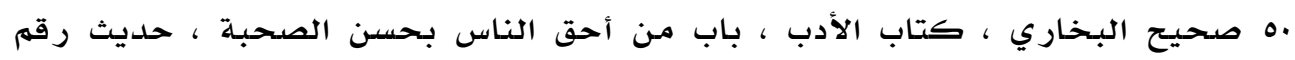
- oqvi

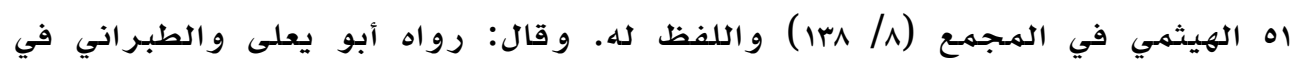

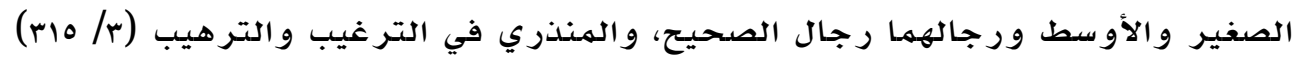

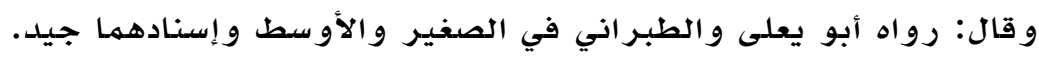

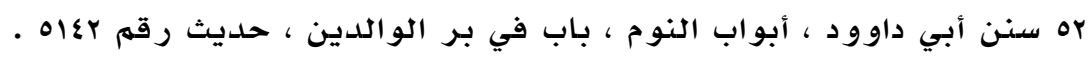

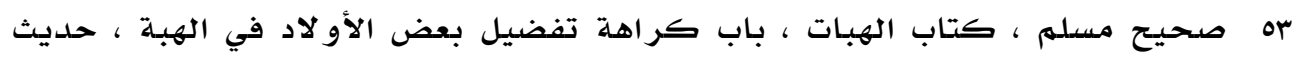
- 
\&ه صحيح البخاري ، كتاب الأدب ، باب رحمة الولد وتقبيله ومعانقته ، حديث رقم

هه سنن الترمدي ، أبواب النكاح ، با بماجاء إذا جاءكه من ترضون دينه فزوجوه ،

$$
\text { حديث ع1.1 }
$$

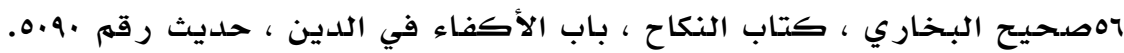

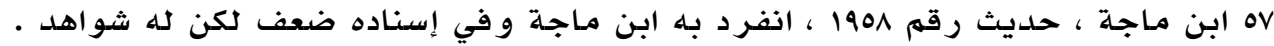

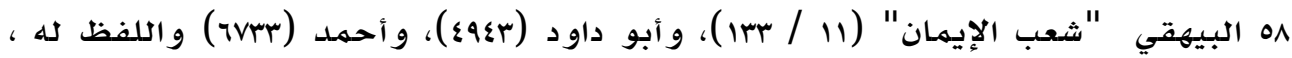
و في إسناده ضعف .

هه سنن الترمذي ، أبواب البر والصللة ، باب ماجاء في رحمة الصبيان ، حديث رقم .194.

•ج عبد السلام ياسين، المنهاج النبوي تربية وتتظيما وزحفا ، الشركة العربية للنشر

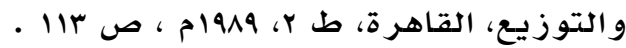

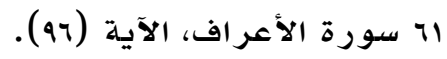

با محمدد فتحي عثمان، القيه الحضدارية في رسالة الإسلام ، ، الدار السعودية ، طا، . \& r ص ،

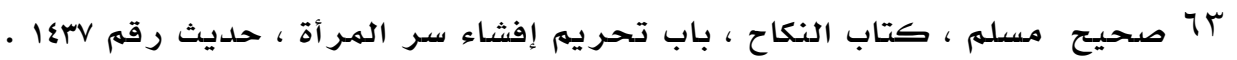

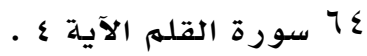

